\title{
EMPIRICAL ANALYSIS OF CORPORATE CREDIT LINES
}

Gabrier Jimenez, José A. Lopez and Jesus Saurina.

Documentos de Trabajo N. 0821

\section{BANCOUESPANA}

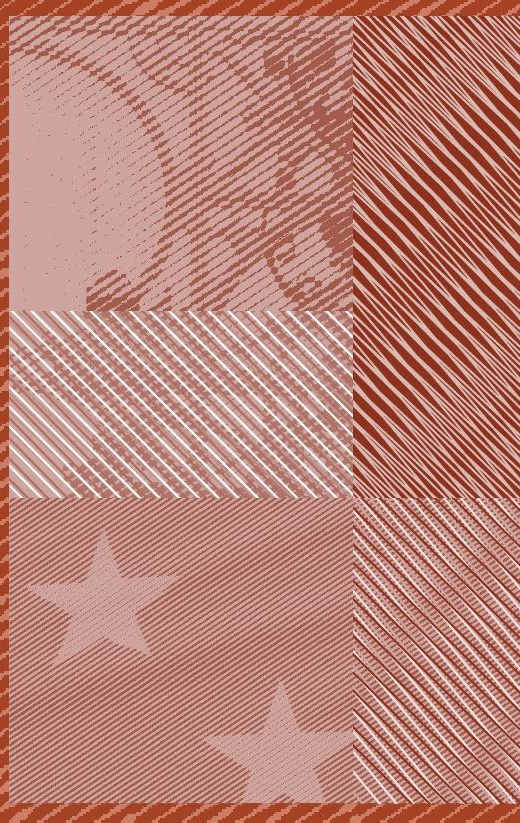


EMPIRICAL ANALYSIS OF CORPORATE CREDIT LINES 
EMPIRICAL ANALYSIS OF CORPORATE CREDIT LINES

Gabriel Jiménez

BANCO DE ESPAÑA

José A. López

FEDERAL RESEVE BANK OF SAN FRANCISCO

Jesús Saurina

BANCO DE ESPAÑA

$\left(^{\star}\right)$ The views expressed here are solely those of the authors and should not be interpreted as reflecting the views of the Banco de España, the Eurosystem, the Federal Reserve Bank of San Francisco or the Board of Governors of the Federal Reserve System. We gratefully acknowledge the comments of Michael Weisbach (the Editor) and an anonymous referee as well as Mark Carey, Ethan Cohen Cole, Adolfo Corrales, Hans Degryse, Kimberly DeTrask, Antonella Foglia, Jan-Pieter Krahnen, Jorge Pérez, Rafael Repullo, Andrea Resti, Til Schuermann, Phil Strahan, Rob Valletta, Dan Wilson and seminar participants at the FDIC's Center for Financial Research Sixth Annual Bank Research Conference, the 2006 GRETA C.R.E.D.I.T. conference, Moody's KMV, the Federal Reserve Banks of New York and San Francisco, and the 2007 Applied Banking Workshop of the Basel Committee on Banking Supervision. 
The Working Paper Series seeks to disseminate original research in economics and finance. All papers have been anonymously refereed. By publishing these papers, the Banco de España aims to contribute to economic analysis and, in particular, to knowledge of the Spanish economy and its international environment.

The opinions and analyses in the Working Paper Series are the responsibility of the authors and, therefore, do not necessarily coincide with those of the Banco de España or the Eurosystem.

The Banco de España disseminates its main reports and most of its publications via the INTERNET at the following website: http://www.bde.es.

Reproduction for educational and non-commercial purposes is permitted provided that the source is acknowledged.

\section{(c) BANCO DE ESPAÑA, Madrid, 2008}

ISSN: 0213-2710 (print)

ISSN: 1579-8666 (on line)

Depósito legal: M. 46254-2008

Unidad de Publicaciones, Banco de España 


\section{Abstract}

Since bank credit lines are a major source of corporate funding, we examine the determinants of credit line usage with a comprehensive database of Spanish corporate credit lines. A line's default status is a key factor driving its usage, which increases as a firm's financial condition worsens. Line usage decreases by roughly $10 \%$ for each year of its life. Lender characteristics, such as the number and length of a firm's banking relationships, are found to affect a firm's usage decisions, and credit line usage is found to be inversely related to macroeconomic conditions.

Keywords: credit lines, firm default, bank lending, exposure at default.

JEL: E32, G18, M21. 


\section{Introduction}

Bank credit lines are a major source of funding for corporations as well as an important business line for commercial banks. Sufi (2008) found that credit lines account for over 80\% of the bank financing provided to U.S. public firms, while Kashyap et al. (2002) found that $70 \%$ of bank borrowing by U.S. small firms is through credit lines. For Spanish firms, the subject of our study, credit lines account for 32\% of banks' total new lending commitments and for $42 \%$ of firms' bank financing, on average. Given this pervasive use of credit lines in practice and the importance assigned to them in theory, as in Holmstrom and Tirole (1998), our goal is to examine empirically the primary factors influencing firms' decisions to use their credit lines.

A clearer understanding of corporate credit line usage should provide meaningful insights into several inter-related questions regarding corporate finance and credit risk management. Sufi (2008) found that credit lines are an important component of firms' liquidity management decisions and that credit line use is determined by an interaction between the firm and its lender primarily through covenants based on performance measures, such as profitability. Our empirical results based on line-level usage data complement this finding, as well as that of Gatev and Strahan (2006) that banks are key liquidity providers for firms. [Note that DeAngelo et al. (2002) present a detailed case study of a public firm's credit line terms and usage.] Our results also highlight the importance of firm default risk in determining credit line use; in particular, we find that firms heading into default draw on their credit lines quite heavily. These results should enhance our understanding of the determinants of a lender's exposure at default (commonly know as EAD) through credit lines, which is an important, but scarcely researched, topic in credit risk management [see Jiménez et al. (2008), for further discussion].

For our analysis, the variable of interest is the percentage of a firm's committed credit line that was actually drawn down in a given year. In fact, to avoid bias due to possible reductions in the commitment amount any time during the life of the credit line, the denominator of the ratio is kept fixed and equal to the total committed credit at the time when the credit line was granted. Our main datasource is the credit register maintained by the Banco de España, the Spanish central bank and primary banking supervisory agency. Known as the Central de Información de Riesgos (CIR), the dataset contains information on loan commitments above €6,000 granted by all banks operating in Spain since 1984 . The dataset contains information on the amounts drawn and available for all corporate credit lines. To our knowledge, this set of corporate credit lines is the most comprehensive examined to date and permits analysis at the level of individual credit lines, as opposed to the firm-level analysis common in the literature [as per Sufi (2008); and Gatev and Strahan (2006)] or the case studies of a particular firm [as in DeAngelo et al. (2002)]. The dataset also contains default information specific to individual credit lines and across all of the borrowers' credit commitments. Hence, we have a complete history of firm default behavior. Finally, since the sample period spans a complete business cycle, we can analyze the impact of macroeconomic conditions on credit line utilization. As many of the credit lines represented in the CIR database are to smaller Spanish firms, our analysis readily extends to smaller firms in other countries, especially Europe and the United States. 
One of our main findings is that credit line usage is very different for firms that eventually default and those that do not, even several years in advance of the default year. "Default" is defined in the CIR database to mean that the firm has not met, or is judged by its creditors to be unable to meet, its scheduled payments. Credit lines to non-defaulting firms in our sample have a median usage ratio of about $43 \%$. Credit lines to firms that eventually default have a median ratio of $50 \%$ five years prior to default, and that value rises to $71 \%$ in the default year. We examine this difference further within a reduced form model using line-specific, borrower-specific, and lender-specific factors as well as general macroeconomic conditions.

Since the CIR database does not contain firm-level accounting data, we merge our credit line dataset with the annual balance sheet reports collected by the Spanish government's Commercial Register and made available electronically since 1992 by Informa-SABI, the Spanish subsidiary of Bureau van Dyck. This merged sample of credit lines is different from the full sample in that the firms are typically larger and the observed default rates are lower. Our empirical results for the merged sample suggest that credit lines to firms with higher expected default probabilities over the next calendar year, which we model using a standard logistic model of firm default, have higher usage rates. Specifically, an increase of one percentage point in expected default probability increases the drawdown rate by $7.4 \%$. The quantification of this "default effect" on how firms use their credit lines is a new finding in this literature. In addition, the age of the credit line is found to reduce the usage rate. This "aging effect" seems to decrease the usage rate by about $10 \%$ per year.

Turning to borrower-specific characteristics, we find that borrowers identified ex-ante as riskier due to prior defaults use less of their new credit lines. This result is roughly analogous to the finding by Sufi (2008) that banks use financial covenants based on profitability to limit credit line use when performance declines. We find that firm size is negatively correlated with credit line usage; this result is consistent with our CIR default indicator, since smaller and younger firms have higher default rates in the CIR database. Firm profitability, as measured by return on assets (ROA), is also negatively correlated with credit line usage, a result consistent with Sufi (2008). Moreover, for our study, firm-specific variables have a significant economic impact; for example, a one standard deviation increase in ROA leads to a decline close to $3 \%$ in the usage ratio. The semi-elasticity for the prior default indicator is, however, much higher at $12.3 \%$. Overall, these results suggest that Spanish banks' monitoring of firms seems to be based more on default history than on near-term financial performance variables.

Since the CIR database contains detailed information on the bank lenders, we examine several questions related to credit supply issues using lender-specific variables. We find that a firm's banking relationships affect their credit line usage in several ways. In particular, as the length of a banking relationship increases, usage rates decrease, and that firms draw less on credit lines managed by their main banks (i.e., the bank that lends most to the firm). Both results are consistent with the argument that banks limit funding to their most dependent borrowers. We also find that credit line usage increases with a firm's number of banking relationships, suggesting, as in Degryse and Ongena (2001), Farinha and Santos (2002), and Fok, Chang and Lee (2004), that less creditworthy firms and those with bad past performance are more likely to establish multiple banking relationships in order to obtain more funds when their main banks deny their requests. 
As noted in both the banking and macroeconomic literatures, the state of the business cycle has a definite effect on firm balance sheets, default probabilities and credit line usage. In our analysis, we find that Spanish GDP growth is negatively correlated with credit line usage; that is, increases in GDP growth are associated with a modest, but statistical significant, decline in credit line usage. This result suggests that credit lines could be a liquidity insurance mechanism for firms, as discussed by Gatev and Strahan (2006) as well as Sufi (2008). However, we do not have information on the interest rates and fees charged on these credit lines needed to examine this finding further.

Even though the CIR database has very limited information on the borrowing firms beyond their default histories, it is worth examining the entire dataset of credit lines without firm-specific balance-sheet variables. The empirical results for this much larger sample, in both the cross-sectional and panel dimension, are similar. Using observed ex-post information, such as firm default status and the number of years to default, as an ex-ante measure of the risk of the credit line, we find that firms that actually default on their credit lines during the sample period have usage rates roughly $40 \%$ higher than non-defaulting firms, and that these usage rates increase by about 13\% per year as the default year approaches. In addition, the age of the credit line is again found to decrease the usage rate by $10 \%$ per year, although this effect is smaller for defaulted firms. The combination of these two effects accounts for most of the differences in usage rates by defaulted and non-defaulted firms and show the robustness of our previous results.

In summary, our study uses data on Spanish firms to examine the factors driving corporate credit line usage. We find that a wide variety of loan-level, firm-level, and lender-level characteristics as well as macroeconomic factors affect these usage rates. The most important factors are a firm's default status (measured either as an ex-ante probability or an ex-post realization), the age of the credit line, certain lender characteristics (such as the length of the banking relationship), and macroeconomic factors. Our finding that drawdowns of credit lines (or EAD) are closely related to line-level default probabilities has important implications for credit risk management and modeling techniques.

The paper is structured as follows. Section 1 provides a short literature review, highlighting empirical studies that informed our choice of explanatory variables. Section 2 describes the CIR database and our sample of credit line usage observations. We present some descriptive statistics and analysis that highlight the importance of firm default on these usage rates. We also discuss the properties of the smaller sample based on merging the CIR database with the Informa-SABI database of borrowers' balance sheet variables. Section 3 presents our regression models and empirical results, and section 4 concludes. 


\section{Literature review}

The extant academic literature related to corporate credit lines examines a variety of issues, ranging from credit line origination, which measures loan supply, to utilization, which measures loan demand. ${ }^{1}$ Melnik and Plaut (1986) found for a surveyed group of U.S. corporations that credit line commitment size was an increasing function of maturity, fees, collateral, firm size, firm liquidity and risk premium. Ham and Melnik (1987) found for a sample of 90 U.S. nonfinancial firms that credit line size was related positively to total sales, borrowed reserves and collateral, while related negatively to interest rate costs. Berger and Udell (1995) found for a sample of small U.S. firms that credit line terms, such as interest rates and collateral requirements, are negatively related with the length of the banking relationship. Shockley and Thakor (1997) examined credit line pricing using data for one large bank. Dennis et al. (2000) examined jointly several credit line terms, such as maturity, interest rate spread, fees and collateralization, at origination and found an important degree of interdependence between these variables. In a case study, DeAngelo et al. (2002) examined the credit line terms and usage of a single public company in light of its overall corporate strategy and eventual default, finding that the bank reduced the committed amount in the credit line as the quality of the firm declined.

A few papers have used corporate credit lines to analyze the role of banks within the financial system. Morgan (1998) uses credit line data from bank surveys collected from the mid-1970s through the mid-1980s to examine the monetary transmission mechanism in the U.S. He shows that loans based on existing credit lines accelerate or remain unchanged after a policy tightening, but that origination of new term loans slows. This distinction reflects a decrease in loan supply and not loan demand. Saidenberg and Strahan (1999) find that firms drew upon their bank lines when access to the commercial paper market was limited in 1998. Gatev and Strahan (2006) further examine banks' role in providing liquidity to the financial system using data on credit lines established to support commercial paper issuance. They find that banks are able to supply credit via these lines when liquidity is low because banks are the natural recipients of funds when this occurs.

Our paper focuses directly on the determinants of corporate credit line use, as in Sufi (2008) and Agarwal et al. (2004). Sufi (2008) takes a corporate finance angle looking at the role of credit lines as an alternative liquidity management tool. Using a sample of public U.S. firms from 1996 to 2003, he finds that credit line access and use was influenced by firm profitability, industry, age and size. He finds the supply of credit lines to be particularly sensitive to firm profitability; a one standard deviation move in EBITDA raises line commitments by $20 \%$ to $25 \%$. He finds that technical defaults (i.e., the violation of line covenants) the year before lead to increased restrictions on the undrawn portions of credit lines, although the reduction seems to be temporary. The amount available from the credit line appears to return to its prior level two years after the violation. Agarwal et al. (2004) examine a proprietary dataset of loan commitments extended by a single bank to 712 privately-held U.S. firms. They find that firms with higher growth commit to larger lines of credit and have a higher rate of line utilization. Furthermore, firms facing higher rates and fees as well as firms facing more uncertainty in their funding needs commit to smaller credit lines.

1. There is a reasonably large literature on consumer credit lines, such as credit card financing [see Gross and Souleles (2002); Calem et al. (2006), and the references therein). Agarwal et al. (2006) examined home equity lines of credit. 
As mentioned, the Spanish CIR database allows us to examine a larger set of credit lines across a wide cross-section of firms and a longer time period than these prior studies. Spanish firms, especially smaller ones, use credit lines primarily for working capital purposes. ${ }^{2}$ In addition, the structure of the CIR data allows us to examine a wider variety of line-specific, firm-specific and borrower-specific factors, as well as general macroeconomic factors, influencing corporate credit line usage. As in Sufi (2008), we examine how defaulting on a credit line (or any related credit) affects credit line usage. In addition, we examine several other line-specific variables, such as the line's lifespan (i.e., the number of years active) as well as the use of collateral. ${ }^{3}$

Regarding firm-specific variables, the CIR database only permits a limited study due to a dearth of accounting variables; in contrast, banking relationship variables, such as prior default status and the nature of firms' banking relationships, as per Petersen and Rajan (1994), are available. However, we merge the CIR database with the Informa-SABI database of Spanish firms, which includes a much richer set of accounting variables. This combined dataset is smaller, but it allows the analysis of such key variables as borrower size, age, leverage and profitability.

For lender-specific variables, the CIR database allows us to examine several features. For example, Coleman et al. (2002) found that lender characteristics impact loan contract terms. Specifically, they found that riskier banks and banks with greater bargaining power lend for longer maturities and charge higher spreads; see also Hao (2004). For our study, we examine the impact that measures of bank risk and main bank status have on corporate credit line use. In addition, Salas and Saurina (2002) found that the type of lending institution has an important effect on corporate lending within the Spanish banking system.

2. Prior studies of credit lines related to public U.S. firms have examined their use as back up financing for commercial paper. However, for most Spanish firms, commercial paper is not an important financing tool. In 2007, outstanding short-term commercial paper by Spanish non-financial firms was $€ 4$ billion (or about $1 \%$ ) relative to total bank lending to non-financial firms of $€ 443$ billion.

3. See Boot and Thakor (1994) for a theoretical discussion of collateral and Jiménez et al. (2006) for empirical evidence from the Spanish banking industry. 


\subsection{The CIR database}

Our datasource is the credit register maintained by the Banco de España, the Spanish central bank and primary banking supervisory agency. Known as the Central de Información de Riesgos (CIR), the dataset contains information on any loan commitment above $€ 6,000$ granted by any bank operating in Spain. The database is essentially a census of all corporate bank lending within Spain from 1984 to 2005, a period that includes the deep recession of 1992 to 1994 and two expansionary periods from the late 1980s through early 1990s and from 1997 onwards. The database is updated at a monthly frequency, but our analysis is conducted at an annual frequency using data as of the last month of each sample year.

The CIR database contains detailed information about loan characteristics such as instrument type (i.e., commercial loan, lease financing, etc.), currency, maturity, collateralization, default status as well as the amount drawn and the total commitment available for credit lines. ${ }^{4}$ The definition of default within the CIR database is that the borrower has loan payments overdue by more than 90 days, which is the legal definition of default in Spain, or it has been classified as a doubtful borrower by the bank (i.e., the lender itself believes there is a high probability of non-payment). Here we differ from Sufi (2008) for whom default means a breach of the existing covenants on the credit line. In addition, information on the borrower's industry and province of headquarters are available. We can also obtain information on the bank-borrower relationship via simple data transformations; for example, the length of a banking relationship, the number of loans outstanding, and the percentage of a firm's credit line commitments provided by a specific bank.

To construct our dataset, we first identify new bank credit lines to non-financial firms in the CIR database. Despite the fact that most credit lines have a maturity of a year or less, it is quite common to find them again the following year with exactly the same characteristics (in particular, the commitment size), changing only the amount drawn. For those cases, following Moral (2006), we assume it is the same credit line, although we classify the observations as having a short maturity. Then, we track those lines through time using all their available characteristics (i.e., borrower, collateral, etc.).

If we find that the commitment amount for a firm's credit line has increased, we treat this as a new credit line in our dataset. However, if the commitment amount declines, we assume that it is the same credit line and keep the commitment amount at the original value. The rationale behind this choice is that an increase in commitment amount reflects a renewed lending relationship, whereas a reduction is simply a risk management technique available to the bank under the existing relationship. Empirical support for this filtering choice is provided by Sufi (2008), who found that credit line commitments were reduced immediately after a technical default only to be returned to their previous levels the year after.

After applying our filtering procedures, we have a sample of 2,078,434 credit line-year observations corresponding to 770,371 credit lines granted to 368,977 firms by 407 banks over a twenty year period. This dataset is a clear improvement over previous studies since it is not limited to a single bank, a specific set of firms, or a narrow time period.

4. Note that the CIR dataset does not contain information on credit line pricing, such as fees and interest rates. For a more detailed explanation of the CIR dataset, see Jiménez and Saurina (2004). 
Roughly $55 \%$ of the observations correspond to credit lines held by a firm with a single bank, 20\% correspond to firms that hold two banking relationships, $10 \%$ with three banks, and the remaining $15 \%$ with more than three. In terms of defaults, $1.80 \%$ of the firms in our sample default on $0.59 \%$ of their credit lines, which make up $0.22 \%$ of our credit-line year observations.

For our analysis, we compute the credit line usage rate as the ratio between the drawn amount at each time and the total commitment size of the line at the time it was granted. In terms of notation, the usage rate of credit line $i$ by firm $j$ as issued by bank $k$ in year $t$ is calculated as

$$
\operatorname{RDRAWN}_{i j k t}=\frac{D R A W N_{i j k t}}{\operatorname{COMMIT}_{i j k t}}
$$

where DRAWN $N_{i j k t}$ is the amount drawn on the credit line at the end of year $t$ and COMMITijkT is the original commitment provided in year $T$ (i.e., the year of the line's origination). Note that since we lock the commitment amount at the origination value, changes in RDRAWN $N_{i j k t}$ are due only to changes in the drawn amount of the credit line. ${ }^{5}$ The histogram of RDRAWNijkt for the whole sample is presented in Figure 1. Just over $15 \%$ of all credit line-year observations are zero, corresponding to 306,274 unique credit lines. Conversely, almost $6 \%$ of these observations are at $100 \%$ usage. For the remaining $79 \%$ of the observations, the distribution is relatively symmetrical around the $50 \%$ value.

\subsection{Univariate event study}

Figure 2 presents one of our most important empirical results. Since the CIR database has information on when firms default on their credit lines, we can transform our credit line usage data from calendar time to event time, where the default year is designated as time zero. For each of the 17 years for which we have event-time data (i.e., 22 sample years, -5 years of prior event time), RDRAWN $N_{i j k t}$ for defaulted credit lines are placed into event time with that year as time zero. These ratios are then tracked for five years prior to (i.e., back to event time -5). The figure presents the median values of the usage rates for defaulted credit lines. We also plot the median value for non-defaulting firms, which is $47 \%$, for reference. Table 1 presents the underlying numbers.

Firms that default on a credit line draw down more than firms that do not default up to three years before the default year. At that point, the median usage rate for defaulting firms is at 58\%. By the default year, the median RDRAWN $N_{i j k t}$ ratio for defaulting firms reaches its maximum of about $70 \%$. This univariate analysis shows that the default status of a firm on a credit line is a major driver of its credit line usage. Our subsequent regression analysis, presented in section 3, confirms that this factor remains the most important one, even after controlling for line-specific, firm-specific and lender-specific factors as well as for general macroeconomic conditions. This empirical result also highlights the importance of modeling

\footnotetext{
5. For this dataset, $29 \%$ of the credit lines experience decreases in their commitment amounts, although we keep them fixed at their original values. The decision to fix the commitment amount at the origination value should create a downward bias for the RDRAWN values for credit lines whose commitment amount declines during the life of the line. That is, since the denominator is not declining in our measure, the RDRAWN value is not rising as it should, assuming that the drawn amount remains the same or declines more slowly than the commitment amount. Therefore, our definition of the usage rate could bias the results against us by making it more difficult to find a relationship between credit line use and measures of credit standing and/or firm performance. Given our strong results presented in section 3, we believe that this bias does not impact our inference and, on the contrary, reinforces our findings.
} 
credit line usage within a risk management context and, in particular, the need to pay attention to the interaction between PD and EAD [see Jiménez et al. (2008), for a detailed analysis of EAD measures using the CIR database].

\subsection{Subsample based on merging with firm balance sheet data}

In line with the existing literature, we extend our analysis by incorporating firm-level accounting data. However, since the CIR database does not contain such data, we merge our credit line dataset with the annual balance sheet reports collected by the Spanish government's Commercial Register and made available electronically since 1992 by Informa-SABI, the Spanish subsidiary of Bureau van Dyck. The Informa-SABI dataset contains the financial statements that the banks had at the time the credit lines were granted and allow us to use a richer set of firm-specific variables in our analysis.

After merging the datasets, the Informa-SABI subsample contains 425,939 credit line observations corresponding to 183,723 credit lines for 85,949 firms granted by 301 banks. The merged sample of credit lines is different from the full sample in two important ways. First, the subsample period is shorter, spanning from 1992 to 2005 with less coverage in the first two years. Since coverage in these early years corresponds to a recession in the Spanish economy, useful observations regarding defaulted credit lines are not available for this subsample. The percentage of defaulted observations is $0.12 \%$, which is lower than the $0.57 \%$ percentage observed in the whole sample for the same time period, again partly due to the loss of observations in the early 1990s. This fact suggests a bias within this sub-sample towards higher-quality firms, which must be taken into account when analyzing the results. However, the histogram and event study corresponding to the Informa-SABI subsample are similar to those of the full sample. Second, and very related to the previous issue the size distribution of the firms within this sample is larger; that is, typically larger firms are recorded in the Informa-SABI database relative to all CIR firms. For example, the median value of the loan commitment for the subsample is $€ 1.3$ million, relative to just $€ 408,000$ for the full sample. This size bias also contributes to the lower default rates in this subsample. 


\section{Econometric modeling}

\subsection{Baseline model}

The baseline model we propose for analyzing the determinants of credit line usage employs the Informa-SABI sample and takes the following form:

$\operatorname{RDRAWN}_{\mathrm{ijkt}}=\beta_{0}+\beta_{1}$ credit line $_{\mathrm{it}}+\beta_{2}$ firm $_{\mathrm{jt}}+\beta_{3}$ bank $_{\mathrm{kt}}+\beta_{4}$ cycle $_{\mathrm{t}}+\eta_{\mathrm{ijk}}+\varepsilon_{\mathrm{it}}$, (2)

where credit lineit is a vector of credit line characteristics; firm it is a vector of firm-specific characteristics; bank $k_{k t}$ is a vector of variables that control for bank characteristics; cycle $_{t}$ is a measure of expected macroeconomic conditions at time $t+1 ; \eta_{i j k}$ is an unobservable credit line effect that is fixed over time and thus also encompasses unobservable firm and bank effects; and $\varepsilon_{i t}$ is an error term. Note that we cluster the standard errors in our calculations on the basis of the firms in the sample, to control for possible within-firm correlation.

We structure the credit line $e_{i t}$ vector of explanatory variables to reflect relevant features of the credit lines and their potential default status. Specifically,

$$
\begin{aligned}
\beta_{1} \text { credit line }_{\text {it }} & =\beta_{11} \mathrm{PD}_{\mathrm{it}} \\
& +\beta_{12} \text { line age }_{i \mathrm{it}} \\
& +\beta_{13} \text { long term }_{\mathrm{i}}+\beta_{14} \text { collateralized }_{\mathrm{i}} .
\end{aligned}
$$

With this specification, we highlight the impact of the credit line's potential default status over year $t$ by generating a model-based default probability, denoted as PDit. As a firm's financial condition deteriorates and its default probability increases, we expect credit line usage to increase and $\beta_{11}>0$. To generate PDit, we first use a standard probit model that includes much of the information available in year $\mathrm{t}-1$ to the bank regarding the firm's financial condition; that is, as in the full model, we include credit line, firm and bank characteristics as well as macroeconomic indicators. ${ }^{6}$ The estimated $P D_{\text {it }}$ is then included as a covariate in the second stage of the estimation, where the standard errors are appropriately adjusted following Murphy and Toppel (1985). The introduction of this variable into the model can be viewed as a form of instrumental variables regression that should mitigate some of the possible endogeniety concerns, especially with respect to firm characteristics.

To model the "age effect" of the credit line, we examine how credit line utilization evolves over the life of the contract using the line ageit variable, which is simply a linear trend. The effect of line age it on the usage rate is unknown. A positive coefficient would indicate that firms increase line use as the credit line ages. However, a negative value would suggest that credit lines are used most intensively in the first year and decline afterwards. We also introduce two time-invariant, credit line characteristics. The long termi variable is equal to one if the reported maturity of the credit line is greater than one year. While these cases account for only $22 \%$ of the observations, longer maturities could be indicative of differences in drawdown patterns. The collateralized; variable is equal to one if the credit line is

6. The specification of our reduced-form default probability model is: $\mathrm{PD}_{\mathrm{it}}=\mathrm{F}\left(\mathrm{C}_{0}+\mathrm{C}_{11}\right.$ long term $\mathrm{i}+\mathrm{C}_{12}$ collateralized $_{\mathrm{i}}+\mathrm{C}_{2}$ firm $_{\mathrm{jt}-1}+\mathrm{C}_{3}$ firm $_{\mathrm{jt}-1}^{2}+\mathrm{C}_{4} \mathrm{firm}_{\mathrm{jt}-1}^{3}+\mathrm{C}_{5}$ bank $_{\mathrm{kt}-1}+\mathrm{C}_{6}$ cycle $\left._{\mathrm{t}-1}\right)$, where the firm, bank and cycle vectors of variables are those defined in the upcoming text plus the liquidity ratio of the firm at time $t-1$; and $F(x)$ is the normal probability distribution function. We use squared and cubic terms to maximize the explanatory power of the PD model. The empirical results are available upon request. 
collateralized, which was found to be significant in Jiménez and Saurina (2004) as well as Jiménez et al. (2006). Only 8\% of the observations correspond to collateralized lines.

In addition to these line-specific variables, the health and performance of the overall firm should also impact its credit lines' usage rates. ${ }^{7}$ Turning to the firm-specific variables available from the Informa-SABI database, our baseline model specifies the firm-specific variable as:

$$
\begin{aligned}
& \beta_{2} \text { firm }_{\mathrm{jt}}=\beta_{21} \ln \text { (total }_{\text {assets }} \text { jt-1 }_{1} \text { ) } \\
& +\beta_{22} \ln \left(1+\text { age of the firm }{ }_{\mathrm{jt}-1}\right) \\
& +\beta_{23} \mathrm{ROA}_{\mathrm{jt}-1} \\
& +\beta_{24} \text { equity/total assets }{ }_{\mathrm{jt}-1} \\
& +\beta_{25} \text { firm risk }_{\mathrm{jt}-1} \\
& +\beta_{26} \ln \left(1+\# \text { years with the bank } \mathrm{jt}_{\mathrm{jt}-1}\right) \\
& +\beta_{27} \ln \text { (\# bank relationships }{ }_{\mathrm{jt}-1} \text { ) } \\
& +\beta_{28} \mathrm{I}_{\text {Sector }, \mathrm{i}}+\beta_{29} \mathrm{I}_{\text {Region }, \mathrm{i}} \text {. }
\end{aligned}
$$

Note that these variables are lagged to better capture the firms' decision process regarding its credit line usage and to avoid possible endogeneity problems, following Sufi (2008) and Jiménez et al. (2006). ${ }^{8}$ The In (total assetsjt-1) variable is the logged book value of the firm. Firm age is also introduced in log form. Firm profitability is measured by book-value return on assets, denoted as $R O A_{j t-1}$, which is the ratio of earnings (before taxes) to total assets. As a proxy for firm solvency, we use the equity/total assetsjt-1 variable. Since larger, older, more profitable and well-capitalized firms are likely to have higher credit quality, we expect a negative relationship between all these variables and credit line usage.

A firm's prior borrowing history should be a key component of its overall funding decisions and its credit line use. Based on the CIR database, we construct the firm riskit-1 variable as a proxy for that history. It is a binary variable equal to one if the firm had defaulted on any other loan prior to time $t$. Note that just $1.5 \%$ of the observations correspond to such firms. Since this firm riskit-1 proxy is available to all lenders, we should expect closer

7. It is challenging to control for firm-level usage rates given the individual credit line-level approach followed in the paper. In particular, a firm's overall degree of liquidity (i.e., its access to both cash and loan commitments) should influence a firm's decision on its credit line usage rates. However, we did not include this variable directly in our analysis due to the potential degree of endogenity between these variables, but it is included indirectly via the PDit variable. As a robustness check (available upon request), we estimated the model including a measure of firm liquidity (cash holdings to total assets), and the inclusion of the variable did not change the estimation results materially. Furthermore, we estimated the model just for firms with a single credit line, whose observations account for about half of the dataset (available upon request). For this regression, we created an alternative usage rate defined as the ratio of the line's drawn amount to the sum of the line's commitment amount and the firm's cash holdings at the line's origination. The estimation results are qualitatively very similar to the full sample results discussed in section IV.C. These robustness results suggest that our indirect inclusion of firm-level liquidity is sufficient to address this endogenity concern.

8. To test whether these variables are redundant in light of their inclusion of the generated $P D_{\text {it }}$ variable, we ran the regression without the $\mathrm{PD}_{\mathrm{it}}$ variable and found no real change in the firm variables' coefficients. These results are available upon request. 
monitoring of firms with prior defaults, which could result in their having lower credit line usage rates (i.e., $\beta_{25}>0$ ). ${ }^{9}$

The next two firm-specific variables are related to the nature of corporate banking relationships, which are proxies for the firm's bargaining power and solvency. The $\ln \left(1+\# y e a r s\right.$ with the bank $\left._{j t-1}\right)$ variable measures the length of the relationship with the bank granting the credit line, which we use to examine the possibility of the so-called "hold-up" problem faced by borrowers; see Boot (2000) for a review of the relationship banking literature. In contrast, the In(\#bank relationshipsjt-1) variable could act in the opposite direction since multiple bank relationships may suggest greater bargaining power by the borrower and hence probably less information exchange with individual lenders $\left(\beta_{27}>0\right)$. On the other hand, several studies have shown that badly performing firms may also initiate more bank relationships [see, for instance, Degryse and Ongena (2001); Farinha and Santos (2002); and Fok, Chang and Lee (2004)], which would imply a higher usage rates for firms with a larger number of bank relationships (i.e., $\beta_{27}>0$ ). Finally, we also include indicator variables for the firm's industry and region of origin.

In line with other studies showing that bank characteristics impact loan access and pricing, we examine whether such variables affect credit line usage. Thus, the third term of our baseline model is constructed as:

$$
\begin{gathered}
\beta_{3} \text { bank }_{\mathrm{kt}}=\beta_{31} \text { main bank }_{\mathrm{ijk}}+\beta_{32} \text { bank share }_{\mathrm{kt}}+\beta_{33} \text { bank NPL ratio } \\
\\
+\beta_{34} \text { savings }_{\text {bank }}+\beta_{35} \text { credit cooperative }_{\mathrm{k}} .
\end{gathered}
$$

The main bank $k_{j k}$ variable equals one if the credit line is handled by the firm's largest lender; just over 39\% of the observations fall into this category. Sharpe (1990) argues that the monitoring process provides the main lending bank with a near monopoly on information regarding borrower credit quality, which could lead to a "hold-up" situation. In this case, the main bank could constrain the liquidity of the firm, suggesting the $\beta_{31}$ coefficient should be negative. As mentioned before, as an alternative to the "hold-up" hypothesis, prior research has shown that firms with past poor performance and firms that more often had past due loan payments are more likely to initiate multiple relationships because of the main bank's unwillingness to provide additional funds. This outcome would imply a positive coefficient on the number of banking relationships and a negative one on the main bank variable (i.e., $\beta_{31}<0$ ) if less creditworthy firms decide to enter into new relationships keeping their main bank unchanged.

The bank sharekt variable is constructed using the CIR dataset as a bank's share of the corporate loan market and is a proxy for bank size. The bank NPL ratiokt variable, constructed as the ratio of a bank's nonperforming loans within the CIR database to its total loans minus the average bank NPL in that year, is a proxy for bank riskiness. The signs on the coefficients for these two variables are unclear a priori, and we view them more as control variables. We also include as control variables the type of the bank, which was shown by Salas and Saurina (2002) to be important within the Spanish economy. Our sample consists

9. Note that our firm risk $\mathrm{jt}_{\mathrm{t}-1}$ variable is similar in spirit to the modeling strategy used by Sufi (2008) regarding his technical default indicator. The difference is that he includes his indicator variable in a regression with other measures of firm risk. In fact, his Table 8 shows that credit line availability depends crucially on that variable and not on other firm specific variables. Hence, a default indicator might possibly be a sufficient statistic for other financial characteristics of a firm. 
of corporate credit lines originated by commercial banks, savings banks and credit cooperatives, which account for $95 \%$ of bank lending in the economy.

Finally, general macroeconomic conditions should play an important role in credit line usage from a theoretical point of view. The literature on the lending channel of monetary policy transmission has established that firms are more constrained in their access to external financing during recessions and hence more likely to draw on their credit lines; see Saidenberg and Strahan (1999) for analysis of a recent such episode. This outcome would imply that firms will use their existing credit lines more in anticipation of economic downturns. As we do not have firm-level data on sales and orders, we use the realized value of real, annual Spanish GDP growth from period $t+1$ as our proxy measure of expected conditions. Our specification is:

$$
\beta_{4} \text { cycle }_{t}=\beta_{41} \text { GDPG }_{t+1} \text {. }
$$

We would expect negative GDP growth rate to cause an increase in credit line usage and thus $\beta_{41}$ to be negative.

Table 2 presents the summary statistics for the dependent and explanatory variables in the Informa-SABI subsample. The distribution of the utilization ratio RDRAWN $N_{i j k t}$ is rather symmetric with mean and median values of $45 \%$ and $44 \%$, respectively. As mentioned, the proportion of observations corresponding to defaulted credit lines is only $0.12 \%$. The year-to-default variable ranges from -6 to 0 , but has average and median values of -1 . The average line age for our sample is 1.4 years. With respect to firm characteristics, the firms are relatively large with a mean of $€ 2.7$ million in total assets and a median value of $€ 1.3$ million. The firms are profitable with an average $R O A$ of $7.2 \%$ and well-capitalized with an average equity-to-assets ratio of $27 \%$. The prior default indicator affects $1.5 \%$ of the observations, which is in line with the $2 \%$ of the full CIR sample. The average length of the bank relationship is 5 years, while firms have, on average, 3.5 lenders. ${ }^{10}$ Note that these values are larger than those observed for the full CIR sample (see section 3.4).

Regarding bank level variables, 39\% of the credit line usage observations are linked to banks that are the largest (or main) lender to the firm. The average loan market share of each bank is relatively low at $0.04 \%$, although the maximum is $14.7 \%$. The deviation of the non-performing loan ratio with respect to the yearly average has a zero mean, with considerable dispersion. As determined by Salas and Saurina (2002), it is important to mention of the types of Spanish banks. Both commercial and savings banks play a significant role in credit and deposit markets, holding similar shares of each market. Yet, their organizational structures are quite different. Commercial banks are for-profit firms under shareholder control, while savings banks (or cajas de ahorros) are effectively commercial entities operated by not-for-profit organizations controlled by depositors, employees and other public and private groups. These two bank types exhibit important differences in non-performing loan ratios, a result that might be relevant for their extension of credit lines. For our sample, commercial and savings banks have a $43 \%$ and 52\% share, respectively, of the credit line-year observations, while credit cooperatives make up the remaining $5 \%$ of the observations. At the beginning of the overall sample period in 1986, commercial banks

10. Note that these latter two variables are winsorized at the $1 \%$ and $99 \%$ percentiles and at the $99 \%$ percentile, respectively, to reduce estimation bias due to outliers. 
dominated the market with a market share of $80 \%$. The progressive entrance of savings banks into corporate lending, mainly after the regulatory changes introduced in the late 1980s, caused a steady decline in the market share of commercial banks in favor of savings banks. $^{11}$

\subsection{Model estimation}

We estimate our baseline model using three econometric techniques. First, we use OLS regression with random effects, which assumes strict exogeneity between the unobserved credit line effects (i.e., $\eta_{i j k}$ ) and the explanatory variables. Note that the common effects also control for firm and bank effects, but we cannot separate them out. The second estimation technique we use is a Tobit model with a double censure, since the RDRAWNijkt variable is bounded by the unit interval. We motivate our use of the Tobit model by thinking of $y^{*}$ as a firm's desired level of credit line utilization as opposed to the observed value $y$. In such cases, OLS techniques could generate downward biased coefficients. By taking account of the censoring, the Tobit model should avoid these biases.

Our third estimation technique is the Within-Groups estimation that treats $\eta_{i j k}$ as a fixed effect. This estimation technique controls for possible correlation of the unobserved fixed effects with the regressors; that is, it helps account for the possibility that banks may have more information about the risk profile of the firm than is captured and observable in our datasets. This technique is our preferred approach, and we highlight these results in the presentation of the empirical results. Note that the use of fixed effects in this estimation technique could diminish the effect of firm- and bank-specific variables and lead to smaller coefficient values.

Finally, it is worth noting that given the large number of observations, denoted as $\mathrm{N}$, in our Informa-SABI subsample as well as the full CIR sample, the estimated standard errors will be very low since they are proportional to $1 / \mathrm{N}$. Thus, almost all our explanatory variables will be statistically significant, despite their relatively small marginal effects on the dependent variable. For this reason, we show both the p-values of the coefficients and the semi-elasticities of the variables. The semi-elasticities measure the percentage change in the dependent variable to unit increases in the explanatory variables expressed in levels or $100 \%$ increases in the explanatory variables expressed in logged form, while the other explanatory variables are kept at their means.

\subsection{Empirical results}

Table 3 presents the estimation results for the baseline model as applied to the Informa-SABI subsample. Columns 1 and 2 contains the estimated results of the OLS and Tobit model, respectively, while the third column presents the Within-Groups results. The last column presents a robustness analysis.

Comparing the first two columns of Table 3, we observe two important results. First, for the majority of the variables of interest, both estimation techniques report similar results regarding the sign of the estimated coefficients. Second, the coefficients are smaller, in absolute terms, for the OLS specification than for the Tobit one, pointing out that the linear model exhibits some downward bias, as we previously discussed. Note that test statistics indicate significant first- and second-order autocorrelation in the residuals of the OLS and Tobit estimations, consistent with the presence of credit line fixed effects that could bias

11. The banking liberalization process in Spain and its impact is discussed by Salas and Saurina (2003). 
the estimated coefficients, in spite of the inclusion of industry and regional dummies in the estimated model. Furthermore, the autocorrelation coefficients for the residuals show a slow decline from the first-order autocorrelation to the fifth. This pattern also supports the existence of persistent differences among credit lines that remain in the data over at least a five-year period.

Focusing on the third column, which address these empirical concerns considering the unobserved credit line effects as fixed, the coefficient on the PDit variable is positive and significant with a semi-elasticity of $7.4 \%$, which implies that a one percentage point increase in a firm's expected default probability causes its credit usage rate to increase by $7.4 \%$. As the mean value of RDRAWN is $45 \%$, an increase of one percentage point on PD would increase the usage rate to $48.2 \%$.

We find that the line age variable also has an important effect on credit line usage. This effect, captured as a linear trend, has a negative and significant coefficient; the semi-elasticity implies that the usage rate decreases about 10\% per year (in both OLS and Within-Groups estimations, slightly higher for the Tobit model) with respect to the average usage rate.

While these two effects are key drivers of credit line usage, we are also interested in the impact that our maturity and collateral indicators have. To examine these effects, we must use the OLS and Tobit results that retain indicator variables in the regression. The maturity indicator has a positive relationship, suggesting that longer maturity lines have a usage rate that is roughly $6 \%$ higher than one-year lines. This result could indicate that firms treat longer-term credit lines as a more stable funding source and use them more. Interestingly, the coefficients on collateral are different for the OLS and Tobit estimations, most probably due to the downward bias in the OLS results due to treating RDRAWN as unbounded. Thus, collateralized credit lines appear to have slightly higher usage rates than uncollateralized lines, with a corresponding semi-elasticity of $4.6 \%$. Since collateral is an ex-ante proxy of credit risk, as found by Jiménez and Saurina (2004), the positive coefficient is in line with the assumption that less creditworthy firms are more likely to drawdown their credit lines.

With regard to the firm-specific variables, column 3 shows that increased firm risk leads to increased credit line usage. Specifically, the Within-Groups coefficients on the firm size and ROA variables are negative and significant, while age of the firm and equity over total assets are also negative although not significant. This empirical evidence is in line with the results obtained by Sufi (2008), who found that profitability is an important element in a bank's decision to grant a corporate credit line. Our results are also in line with the assumption that less creditworthy firms (i.e., smaller and less profitable firms) use their credit lines more intensively than higher-quality ones. In contrast, the firm risk indicator variable has a semi-elasticity of $-12.3 \%$, suggesting that firms with a prior default have usage rates of $39.4 \%$, relative to the sample average of $45 \%$. Overall, these firm-level results suggest that Spanish banks' monitoring of firms seems to be based more on default history than on near-term financial performance variables.

The length of the banking relationship is also negatively related with usage, suggesting both that older customers do not draw down their credit lines as much and that a potential hold-up problem may exist. The higher usage rates found for banks with multiple bank relationships is also consistent with borrowers facing a potential hold-up problem. 
Alternatively, it might be possible that credit lines are an expensive and flexible source of funds. That might explain why firms as they grow in assets, age or confidence (i.e. longer relationships) tend to draw less from them and, arguably, use more of other banking instruments. Moreover, as a bank relationship lengthens, the firm should be able to obtain additional benefits, such as longer loan maturities, looser collateral requirements or easier availability of funds in case of a common (or non-idiosyncratic) negative shock.

With respect to the lender characteristics, the main bank variable has a semi-elasticity of $-5.9 \%$, which lowers the usage rate to $42 \%$ relative to the average value of $45 \%$. This result suggests that banks use their relative advantage in banking relationships to limit firm borrowing. Bank size, proxied for as the total share of lending within the CIR database, is not statistically significant, but credit lines granted by higher-risk banks (i.e., higher NPL with respect to the yearly average) are drawn slightly more than average. This result seems to suggest a possible supply effect where riskier banks allow more line usage (by riskier borrowers). Regarding differences across bank types, we need to examine the Tobit parameter estimates and find that credit lines granted by savings banks and cooperatives have lower usage rates than commercial banks. The result may be due to these banks' entry to the corporate banking sector via lending to higher-quality firms, or perhaps to their more conservative policies than commercial banks, as per Salas and Saurina (2002).

Finally, our results indicate a significant negative relationship between macroeconomic conditions and credit line use. The Within-Groups estimate of the macroeconomic coefficient is negative with a semi-elasticity of $-0.9 \%$. As suggested in the theoretical literature, such as Thakor (2005), firms use their credit lines to secure liquidity during worsening economic conditions, but instead rely more on their own cash flows or other cheaper sources of liquidity during periods of improved conditions. Unfortunately, we do not have further information, such as the interest rates paid on these credit lines, to examine whether credit lines are used as a liquidity insurance mechanism with a corresponding premium over other funding sources.

The last column of Table 3 presents a robustness test of our results to an alternative definition of the dependent variable. As discussed in section 2.1, our RDRAWN $N_{i j k t}$ measure is defined so as to vary only due to changes in the numerator's drawn amount over the life of the credit line, even though we do observe variation in the denominator's commitment amount. Since $71 \%$ of the 183,723 credit lines (or 130,141 credit lines and 264,272 observations) do not experience a change in their commitment amount over the life of the line, we present the Within-Groups regression results for this subsample to see if our definition introduces any bias. The subsample results are consistent with those for the entire sample in presented in column 3. The only exceptions are the lack of significance for the firm risk and relationship length variables. This last result lowers the concern about the potential hold-up problem. Thus, we conclude that our definition of RDRAWN is not hindering our qualitative results and inference.

In summary, we find that corporate credit line usage is affected by a wide variety of factors. Our results suggest that firm performance (especially as summarized by our default probability variable), line age, prior default history, profitability ratios, credit supply (i.e., bank-firm relationships) and the cyclical position of the economy variables are the most important. 


\subsection{Analysis of the full CIR sample}

As mentioned before, the CIR database does not contain detailed firm-level information. However, it does contain many more defaulted credit line observations; $0.57 \%$ relative to $0.12 \%$. In this section, we use the information available to examine the robustness of our subsample results within the full CIR sample. Table 4 presents the summary statistics for the regression variables. The main differences between the firms in the samples are that they draw more on their credit lines; have a higher default rate; have a worse default history; and are more bank-reliant (i.e., higher percentage with a main bank and fewer banking relationships).

We again use the baseline model described before, but we redefine the credit lineand firm-specific vectors of variables. The credit line-specific vector is

$$
\begin{aligned}
\beta_{1} \text { credit line }_{\text {it }}=\left(\beta_{11}+\right. & \beta_{12} \# \text { years from default } \\
& \left.+\left(\beta_{14}+\beta_{15} \# \text { Defaulted }_{\mathrm{i}}\right) \cdot \text { line }_{\text {age }} \text { years from default }_{\mathrm{it}}^{2}\right) \cdot \text { Defaulted }_{\mathrm{i}} \\
& +\beta_{16} \text { long term }_{\mathrm{i}}+\beta_{16} \text { collateralized }_{\mathrm{i}} .
\end{aligned}
$$

With this specification, we highlight the impact of the credit line's ex-post default status over the sample period and its age effects. The "default effect" captured in the first term measures both the impact of credit line default through the Defaulted indicator variable, which equals one for credit lines that are defaulted on during our sample period, and through its prior-to-default effect. We set this latter variable equal to the actual number of years prior to default for defaulting credit lines, such that it is an ordinal variable less or equal than zero (i.e., it takes the values $-11,-10, \ldots, 0$ ). We also introduce a quadratic effect to allow for a greater flexibility of response. From the descriptive analysis presented earlier, we expect a positive sign for both the $\beta_{12}$ and $\beta_{13}$ coefficients since usage rates rise as the default year approaches. Moreover, if credit lines to riskier borrowers have higher usage rates, we expect a positive $\beta_{11}$ coefficient, which would capture the difference in levels of usage rates between defaulted and non-defaulted credit lines.

As before, we model the "age effect" of the credit line with the line ageit variable, which is simply a linear trend. Now, we also permit a different slope for defaulted credit lines by using an interaction term with the Defaultedi indicator. The effect of Line age it on the usage rate is unknown. A positive coefficient would indicate that firms increase line use as the credit line ages. However, a negative value would suggest that credit lines are used more intensively during the first year and decline afterwards. If this is the case, we expect a smaller effect for defaulted credit lines, since their usage rates are higher. Thus, if $\beta_{14}$ is estimated to be negative, the estimated $\beta_{15}$ is expected to be positive, such that $\beta_{14}+\beta_{15}<0$. Finally, we retain the long term $i$ and collateralizedi variables as before (at least in the OLS and Tobit estimates).

The firm-specific variables based solely on the CIR database are introduced into the model as:

$$
\begin{aligned}
& \beta_{2} \text { firm }_{\mathrm{jt}}=\beta_{21} \ln (1+\text { age as borrower } \\
& \mathrm{jt-1}-1+\beta_{22} \text { firm } \text { risk }_{\mathrm{jt}-1} \\
&+\beta_{23} \ln (1+\# \text { years with the bank } \\
&+\beta_{24-1} \ln (\# \text { bank relationships } \\
& \mathrm{jt-1}-1
\end{aligned}
$$


The $\ln \left(1+\right.$ Age as borrower t $\left.-1^{-1}\right)$ variable is the only proxy for age available within the CIR database and is constructed as the logged number of years since the first time a loan was granted to the firm. The expected sign on $\beta_{21}$ is negative although this is only a control variable in this specification. The other variables are the same as before. Note that, as before, we highlight the Within-Groups parameter estimates.

Table 5 reports the three sets of regression results for the merged dataset. Since the ex-post default indicator is a binary variable, it cannot be examined using the Within-Groups estimation. Focusing on the other estimation techniques, the coefficient on the ex-post default indicator variable is positive and significant with a semi-elasticity of about $38 \%$, which implies that defaulted credit lines have a usage rate $38 \%$ higher than non-defaulted ones. Since the average usage rates for the defaulted and non-defaulted firms in the sample are $63 \%$ and $47 \%$, the model's $38 \%$ increase $(47 \%$ * $1.38=65 \%)$ seems reasonable. This effect is clearly much stronger than the ex-ante case used in the Informa-SABI subsample. The two interacted years-to-default variables show a positive and very significant relationship, suggesting an increasing use of credit lines as a firm's time to default approaches, as suggested in Figure 3. The semi-elasticity of these two terms in the third column is about $13 \%$, which means that one year closer to default raises the usage rate $13 \%$ relative to the average usage rate.

We also find that our line age variable is important here as well. The age effect captured by a linear trend has a negative and significant coefficient for all estimation techniques, which implies the usage rate decreases by about 10\% per year with respect to the average usage rate. If we examine the interaction between line age and the Defaultedi indicator using the Tobit estimation results, we find that the age effect is weaker for defaulted credit lines at a $4.5 \%$ decrease $(=-10.4 \%+5.9 \%)$. The countervailing positive default effect and negative age effect suggest an interesting U-shaped pattern in credit line, as illustrated in Figure 3. Using the average values for all the other explanatory variables, Figure 3 shows the impact of the age effect for non-defaulting firms and the joint impact for defaulting firms. Starting at seven years prior to default and with a new line, usage rates are at $54.5 \%$ and $57.3 \%$, respectively. As we approach default, the age effect linearly lowers the usage rate for non-defaulting firms to $6 \%$ by the default year. For defaulting firms, this linear decline is more gradual and is outweighed by the default effect starting at $45.3 \%$ four years prior to default to reach the $59.3 \%$ by default year.

While these two effects are the main drivers of credit line usage, the maturity and collateral variables also have an impact, as shown in the second column of Table 5 . The maturity indicator has an important impact, where longer maturity lines have usage rates that are 5.2\% higher than one-year lines. Collateralized credit lines are found to have slightly higher usage rates than uncollateralized lines, as found in the subsample results.

Turning to the limited firm-specific effects in the CIR dataset, the firm's age as a borrower (i.e., how many years it has been in the CIR database) has a positive relationship with credit line usage. However, this result is not consistent across the three estimation methods and also differs from Informa-SABI results in Table 3. Probably age as borrower is far from being a perfect proxy for the age of the firm, the variable it tries to proxy. As before, the firm riskjt-1measure based on prior defaults is highly negatively correlated with credit line use, suggesting that lower-quality borrowers use their lines more carefully or are closely monitored by their lenders. This is consistent across the three models and with Table 3 
results, underlining the importance of credit history in order to use the credit lines. The results for the remaining variables are similar to those of the subsample results.

We observe a negative relationship between credit line usage and the main bank variable as well as with the length of banking relationship variables, but a positive relationship with the number of banking relationships. These results continue to suggest that possible hold-up situations may be present in the Spanish banking system. However, given the overall value provided to firms by banking relationships, it is challenging to achieve a clear empirical conclusion on this point.

For lender characteristics, the results vary slightly from the subsample results. Here, bank share is negative, but the bank NPL ratio is not statistically significant. Thus, smaller banks allow for a higher use of credit lines, which means that they allow riskier borrowers to draw down their lines. As before, credit lines granted by savings banks and cooperatives have lower usage rates than commercial banks.

Finally, our full sample results also imply a significant negative relationship between macroeconomic conditions and credit line use, reinforcing the liquidity insurance role they seem to play for firms, including the smaller ones. 


\section{Conclusions}

In this paper, we examine corporate credit line usage within the Spanish economy. The analysis is based on the Spanish Credit Register, a huge transaction-based database known as the Central de Información de Riesgos (CIR), which covers all Spanish bank lending over the last twenty years, as well as the Informa-SABI database containing firm-level balance sheet data. The extensive nature of both datasets allows us to examine the determinants of corporate credit line usage as a function of loan-specific, firm-specific, and lender-specific factors as well as general macroeconomic conditions.

One of our main findings is that credit lines are drawn down more by firms that eventually default on these lines than firms that do not. This usage rate is higher in a statistically significant way from at least three years prior to default and increases monotonically as default approaches. As far as we know, this empirical finding is new to the literature and has important implications for credit risk modeling and management in that exposure at default (EAD) in corporate credit lines cannot be considered independent of firm default probability. Moreover, given the option characteristics of credit lines, our results provide stylized facts that any pricing model must account for.

From a multivariate perspective, our analysis suggests that a wide variety of loan-level, firm-level, lender-level and macroeconomic factors determine corporate credit line usage. We find that credit line default status, both ex-ante in the form of an expected default probability an ex-post as a default indicator variable, has a strong positive relationship with credit line usage. We also find that line age has a strong negative relationship with line usage. Borrowers identified ex-ante as riskier (i.e., those that have defaulted before) access their credit lines less, a result that is analogous to the firm profitability result found by Sufi (2008) and is perhaps due to tighter bank monitoring.

For a subsample of credit lines for which firm-level accounting data is available, we find that smaller and less profitable firms use their credit lines more intensively. We also find that credit line use is inversely related to the business cycle as proxied for by real GDP growth. Thus, credit lines seem to work as a liquidity insurance mechanism for firms, as discussed by Gatev and Strahan (2005) and Sufi (2008).

Our results provide large-sample evidence on the determinants of corporate credit line use that reinforces a number of related findings in the literature. In addition, our results have direct implications for modeling exposure at default (EAD), a key element of credit loss and loan pricing calculations. While we find EAD to be a random variable, most credit risk models currently treat EAD as known. Even more surprisingly, EAD is commonly assumed to be independent of a firm's default probability (commonly known as PD). Our analysis indicates that $\mathrm{PD}$ and EAD are closely related and that this correlation must be accounted for to generate accurate credit risk measures. Our empirical results advance the understanding of the determinants of EAD and provide some of the necessary foundations for future work on that subject. 


\section{REFERENCES}

AGARWAL, A., B. W. AMBROSE and C. LIU (2006). "Credit Lines and Credit Utilization", Journal of Money, Credit and Banking, 38, pp. 1-22.

AGARWAL, S., S. CHOMSISENGPHET and J. C. DRISCOLL (2004). Loan commitments and private firms, Finance and Economics Discussion Series 2004-27, Board of Governors of the Federal Reserve System.

BERGER, A.N., and G. F. UDELL (1995). "Relationship lending and lines of small firm finance”, Journal of Business, 68 , pp. 355-82.

BООT, A. W. A. (2000). "Relationship banking: What do we know?", Journal of Financial Intermediation, 9, pp. 7-25.

BOOT, A., and A. THAKOR (1994). "Moral hazard and secured lending in an infinitely repeated credit market game", International Economic Review, 35, pp. 899-920.

CALEM, P. S., M. B. GORDY and L. J. MESTER (2006). "Switching costs and adverse selection in the market for credit cards: New evidence”, Journal of Banking and Finance, 30, pp. 1653-1685.

COLEMAN, A. D. F., N. ESHO and I. G. SHARPE (2006). "Do Bank Characteristics Influence Loan Contract Terms?", Journal of Financial Services Research, 30, pp. 177-198.

DeANGELO, H., L. DeANGELO and K. H. WRUCK (2002). "Asset Liquidity, Debt Covenants and Managerial Discretion in Financial Distress: The Collapse of L.A. Gear", Journal of Financial Economics, 64, pp. 3-34.

DEGRYSE, H., and S. ONGENA (2001). "Bank Relationships and Firm Performance", Financial Management, 30 (1), pp. 9-34.

DENNIS, S., D. NANDY and I. G. SHARPE (2000). "The Determinants of Contract Terms in Bank Revolving Credit Agreements", Journal of Financial and Quantitative Analysis, 35, pp. 87-110.

FARINHA, L. A., and J. A. C. SANTOS (2002). "Switching from Single to Multiple Bank Lending Relationships: Determinants and Implications", Journal of Financial Intermediation, Vol. 11, Issue 2, pp. 124-141.

FOK, R. C. W., Y. C. CHANG and W. T. LEE (2004). "Bank Relationships and Their Effects on Firm Performance around the Asian Financial Crisis: Evidence from Taiwan", Financial Management, 33 (2), pp. 89-112.

GATEV, E., and P. STRAHAN (2006). "Banks' advantage in hedging liquidity risk: Theory and evidence from the commercial paper market", Journal of Finance, 61 (2), pp. 867-892.

GROSS, D., and N. SOULELES (2002). "An empirical analysis of personal bankruptcy and delinquency", Review of Financial Studies, 15 (1), pp. 319-347.

HAM, J. C., and A. MELNIK (1987). "Loan demand: An empirical analysis using micro data", Review of Economics and Statistics, 8 (4), pp. 251-263.

HAO, L. (2004). Bank Effects and the Determinants of Loan Yield Spreads, Working Paper, Schulich School of Business, York University.

HOLMSTROM, B., and J. TIROLE (1998). "Private and public supply of liquidity", Journal of Political Economy, 106 , pp. 1-40.

JIMÉNEZ, G., J. A. LÓPEZ and J. SAURINA (2008). EAD Calibration for Corporate Credit Lines, Manuscript, Federal Reserve Bank of San Francisco.

JIMÉNEZ, G., V. SALAS FUMÁS and J. SAURINA (2006). "Determinants of Collateral". Journal of Financial Economics, 81, pp. 255-281.

JIMÉNEZ, G., and J. SAURINA (2004). "Collateral, Type of Lender and Relationship Banking as Determinants of Credit Risk", Journal of Banking and Finance, 28, pp. 2191-2212.

KASHYAP, A., R. RAJAN and J. STEIN (2002). "Banks as liquidity providers: An explanation for the co-existence of lending and deposit-taking", Journal of Finance, 57, pp. 33-73.

MELNIK, A., and S. E. PLAUT (1986). "Loan commitment contracts, terms of lending and credit allocation", Journal of Finance, 41, pp. 425-435.

MORAL, G. (2006). "EAD Estimates for Facilities with Explicit Limits", in B. Engelmann and R. Rauhmeier (eds.), The Basel Il Risk Parameters, pp. 197-242.

MORGAN, D. (1998). "The Credit Effects of Monetary Policy: Evidence Using Loan Commitments", Journal of Money Credit and Banking, Vol. 30, Issue 1, February, pp. 102-118.

MURPHY, K. M., and R. H. TOPEL (1985). "Estimation and Inference in Two-Step Econometric Models", Journal of Business and Economic Statistics, 3, pp. 370-379.

PETERSEN, M., and R. RAJAN (1994). "The Benefits of Lender Relationships: Evidence from Small Business Data", Journal of Finance, 49, pp. 3-37.

SAIDENBERG, M. R., and P. E. STRAHAN, (1999). Are Banks Still Important for Financing Large Businesses?, Federal Reserve Bank of New York, Current Issues in Economics and Finance, 5 (12).

SALAS, V., and J. SAURINA (2002). "Credit Risk in Two Institutional Regimes: Spanish Commercial and Savings Banks", Journal of Financial Services Research, 22, pp. 203-224.

- (2003). "Deregulation, Market Power and Risk Behavior in Spanish Banks", European Economic Review, 47, pp. 1061-1075.

SHARPE, S. A. (1990). "Asymmetric Information, Bank Lending, and Implicit Contracts: A Stylized Model of Customer Relationships", Journal of Finance, 45, pp. 1069-1087.

SHOCKLEY, R., and A. THAKOR (1997). "Bank loan commitment contracts: data theory and tests", Journal of Money, Credit, and Banking, November, pp. 517- 534.

SUFI, A. (2008). "Bank lines of credit in corporate finance: an empirical analysis", Review of Financial Studies, forthcoming.

THAKOR, A. V. (2005). "Do loan commitments cause overlending?", Journal of Money, Credit and Banking, 37, pp. 1067-1099. 
Table 1.

Mean and median values of usage rate for the full CIR sample of defaulted credit lines

\begin{tabular}{r|rrr}
\multicolumn{1}{c|}{$\begin{array}{l}\text { Years } \\
\text { from default }\end{array}$} & M obs. & Median & Mean \\
\hline-5 & 85 & 50.0 & 52.1 \\
-4 & 228 & 50.0 & 50.3 \\
-3 & 717 & 58.3 & 56.2 \\
-2 & 1,939 & 62.1 & 60.4 \\
-1 & 4,512 & 66.7 & 64.2 \\
0 & 4,512 & 71.1 & 64.7 \\
\hline
\end{tabular}


Table 2.

Descriptive statistics for the Informa-SABI sample

\begin{tabular}{|c|c|c|c|c|c|c|c|}
\hline $\begin{array}{l}\text { No. of observatios: } 425,939 \\
\text { No.of credit lines: } 183,723 \\
\text { No.of firms: } 85,949 \\
\text { Sample period: } 1993-2005\end{array}$ & Mean & S.D. & Min & Q25 & Median & Q75 & Max \\
\hline \multicolumn{8}{|l|}{ Credit Line Characteristics } \\
\hline $\operatorname{RDRAWN}_{\mathrm{ijkt}}(\%)$ & 44.91 & 33.34 & 0.00 & 13.33 & 44.44 & 74.49 & 100.00 \\
\hline Defaulted credit line $e_{i}(0 / 1)$ & 0.001 & 0.04 & 0.00 & 0.00 & 0.00 & 0.00 & 1.00 \\
\hline Life of the $\operatorname{loan}_{\text {it }}$ & 1.36 & 1.56 & 0.00 & 0.00 & 1.00 & 2.00 & 18.00 \\
\hline Long term $\mathrm{i}_{\mathrm{i}}(0 / 1)$ & 0.22 & 0.41 & 0.00 & 0.00 & 0.00 & 0.00 & 1.00 \\
\hline Collateralized $_{i}(0 / 1)$ & 0.08 & 0.28 & 0.00 & 0.00 & 0.00 & 0.00 & 1.00 \\
\hline \multicolumn{8}{|l|}{ Firm Characteristics } \\
\hline Total assets ${ }_{\mathrm{jt}-1}$ (thousand of euros) & $2,723.78$ & $2,851.08$ & 43.68 & 498.15 & $1,345.20$ & $4,446.00$ & $7,900.09$ \\
\hline Age of the firm $\mathrm{jt}_{\mathrm{j}-1}$ & 11.25 & 7.65 & 1.00 & 5.00 & 10.00 & 16.00 & 26.00 \\
\hline $\mathrm{ROA}_{\mathrm{jt}-1}(\%)$ & 7.23 & 7.95 & -37.68 & 3.08 & 6.10 & 10.31 & 60.55 \\
\hline Equity/Total assets $\mathrm{it}-1(\%)$ & 27.03 & 19.12 & 0.01 & 12.14 & 23.09 & 37.95 & 100.00 \\
\hline Firm risk $_{\mathrm{jt-1}}(0 / 1)$ & 0.01 & 0.12 & 0.00 & 0.00 & 0.00 & 0.00 & 1.00 \\
\hline No. of years with the bank $\mathrm{j}_{\mathrm{jt}-1}$ & 5.09 & 4.29 & 0.00 & 2.00 & 4.00 & 7.00 & 21.00 \\
\hline No. of bank relationships $\mathrm{jt}_{\mathrm{jt}}$ & 3.48 & 2.93 & 0.00 & 1.00 & 3.00 & 5.00 & 9.00 \\
\hline PD (\%) & 0.04 & 0.09 & 0.00 & 0.01 & 0.02 & 0.05 & 5.12 \\
\hline \multicolumn{8}{|l|}{ Bank Characteristics } \\
\hline Main bank $_{\text {ikt }}(0 / 1)$ & 0.39 & 0.49 & 0.00 & 0.00 & 0.00 & 1.00 & 1.00 \\
\hline Bank share $_{\mathrm{kt}}(\%)$ & 0.04 & 0.06 & 0.00 & 0.01 & 0.02 & 0.09 & 14.72 \\
\hline Bank NPL ratio ${ }_{\mathrm{kt}}(\%)$ & 0.00 & 0.57 & -9.05 & 0.00 & 0.00 & 0.00 & 98.70 \\
\hline Savings bank $k_{k}(0 / 1)$ & 0.52 & 0.50 & 0.00 & 0.00 & 1.00 & 1.00 & 1.00 \\
\hline Credit cooperative $_{k}(0 / 1)$ & 0.05 & 0.22 & 0.00 & 0.00 & 0.00 & 0.00 & 1.00 \\
\hline \multicolumn{8}{|l|}{ Cycle Characteristics } \\
\hline $\operatorname{GDPG}_{\mathrm{t}+1}(\%)$ & 3.53 & 0.72 & 2.38 & 3.00 & 3.43 & 3.86 & 5.04 \\
\hline
\end{tabular}

$R D R A W N_{i j k t}$ is the ratio of the amount drawn at to the amount available (drawn plus undrawn) when the credit lines was granted of a credit line $i$ to firm $j$ by bank $k$. The variable Defaulted credit line $e_{i}$ takes one if the credit line defaults anytime during its life and zero otherwise. The variable Life of the loan $_{i t}$ measures the number of years since the credit line was grated; Long term $m_{i}$ is a dummy variable worth 1 if the maturity of the credit lines is longer that 1 year and 0 otherwise Collateralized ${ }_{i}$ is a dummy variable worth 1 if the credit line is collateralized and 0 otherwise; Ln(Total assets ${ }_{j t-1}$ ) proxies for the size of the firm; Age of the firm jt-1 $_{1}$ is the number of years since the firm was set up; profitability is measured by $R O A_{j t-1}$, the ratio between EBIT and total assets; Equity/Total assets ${ }_{j t-1}$ measures the

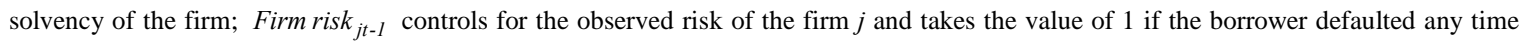
until $t$; No. of years with the bank ${ }_{j t-1}$ measures the number of years since the firm got the first loan with the bank; No. of bank relationships ${ }_{j t-1}$ is the number of banks with which the firm has loans;. The variable $\mathrm{PD}_{\text {it }}$ is a generated, one-year default probability for the credit line. Main bank ${ }_{i k t}$ is a dummy variable that takes one if the bank that granted the loan is the main bank for the firm

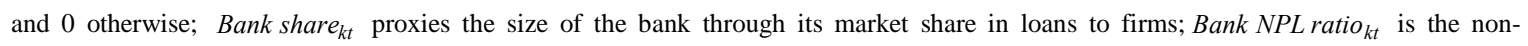
performing loan ratio of bank $k$ at time $t$ with respect to the NPL ratio of the year; Savings bank $k_{k}$ is a dummy variable worth 1 if the bank is a savings bank, 0 otherwise; Credit cooperative $k$ is a dummy variable worth 1 if the bank is a credit cooperative, 0 otherwise; and $G D P G_{t+1}$ is the GDP rate of growth of the Spanish economy at $\mathrm{t}+1$. 
Table 3.

Estimation of the baseline model for the Informa-SABI sample

\begin{tabular}{|c|c|c|c|c|c|c|c|c|}
\hline \multirow[t]{2}{*}{$\begin{array}{l}\text { Estimation Method } \\
\text { No. of observatios: } 425,939 \\
\text { No. of credit lines: } 183,723 \\
\text { No. of firms: } 85,949 \\
\text { Sample period: } 1993-2005 \\
\text { Dependant variable: RDRAWN }\end{array}$} & \multicolumn{2}{|c|}{ Model 1} & \multicolumn{2}{|c|}{ Tobit with Random effects } & \multicolumn{2}{|c|}{ Within-Groups } & \multicolumn{2}{|c|}{\begin{tabular}{|l}
\multicolumn{1}{|c|}{ Within-Groups } \\
No. of observatios: 264.272 \\
No. of credit lines: 130.141 \\
No. of firms: 72.701 \\
Sample period: $1993-2005$ \\
Dependant variable: RDRAWN \\
CONSTA \\
$\begin{array}{l}\text { CONT COMMITMENT } \\
\text { Model 4 }\end{array}$ \\
\end{tabular}} \\
\hline & Coefficient & $\begin{array}{l}\text { Semi- } \\
\text { elasticity }\end{array}$ & Coefficient & $\begin{array}{l}\text { Semi- } \\
\text { elasticity }\end{array}$ & Coefficient & $\begin{array}{l}\text { Semi- } \\
\text { elasticity }\end{array}$ & Coefficient & $\begin{array}{l}\text { Semi- } \\
\text { elasticity }\end{array}$ \\
\hline \multicolumn{9}{|l|}{$\begin{array}{l}\text { Credit Line Characteristics } \\
\text { Default effect }\end{array}$} \\
\hline $\begin{array}{l}\left.\text { Prob(Default } t_{i t}=1\right)_{i t-1} \\
\text { Age effect }\end{array}$ & 3.516 & 7.8 & $4.970 \ldots$ & 9.0 & $3.334 *$ & 7.4 & $5.099 *$ & 11.4 \\
\hline $\begin{array}{l}\text { Life of the loan it } \\
\text { Other effects }\end{array}$ & $-4.597^{* * *}$ & -10.2 & $-6.475^{\star \star \star}$ & -11.7 & -4.526 & -10.1 & $-3.219 * * *$ & -7.2 \\
\hline Long term $\mathrm{i}_{\mathrm{i}}(0 / 1)$ & $3.073^{\star \star *}$ & 6.8 & $3.503 * * *$ & 6.3 & -- & -- & -- & -- \\
\hline Collateralized $_{i}(0 / 1)$ & $0.425 *$ & 0.9 & $2.539 * * *$ & 4.6 & -- & -- & -- & -- \\
\hline \multicolumn{9}{|l|}{ Firm Characteristics } \\
\hline $\operatorname{Ln}\left(\right.$ Total assets $\left.s_{j-1}\right)$ & -0.897 *** & -2.0 & -1.027 & -1.9 & -0.980 * & -2.2 & -0.496 & -1.1 \\
\hline $\operatorname{Ln}\left(1+\right.$ Age of the firm $\left.m_{j-1}\right)$ & -0.144 & -0.3 & $-0.286 * *$ & -0.5 & -0.696 & -1.6 & 1.438 & 3.2 \\
\hline $\mathrm{ROA}_{\mathrm{jt}-1}$ & $-0.197 \ldots$ & -0.4 & $-0.183^{* * *}$ & -0.3 & $-0.042^{* * *}$ & -0.1 & $-0.041 \ldots$ & -0.1 \\
\hline Equity/Total assets & -0.138 *** & -0.3 & -0.156 *** & -0.3 & -0.016 & 0.0 & $-0.049 *$ & -0.1 \\
\hline Firm risk $\mathrm{j} t-1_{1}$ & $-2.801+* *$ & -6.2 & $-3.525 * * *$ & -6.4 & $-5.520 * * *$ & -12.3 & -2.131 & -4.7 \\
\hline $\operatorname{Ln}\left(1+\right.$ No. of years with the bank $\left.k_{j-1}\right)$ & -2.517 *** & -5.6 & -2.582 *** & -4.7 & $-1.593+* *$ & -3.5 & 0.814 & 1.8 \\
\hline $\operatorname{Ln}\left(\right.$ No. of bank relationships $\left.s_{\mathrm{jt}-1}\right)$ & 4.940 *** & 11.0 & 5.049 & 9.1 & $0.579 *$ & 1.3 & $1.330 * * *$ & 3.0 \\
\hline \multicolumn{9}{|l|}{ Bank Characteristics } \\
\hline Main bank $k_{i k t}$ & $2.290 * * *$ & 5.1 & $1.034 * * *$ & 1.9 & $-2.639 * * *$ & -5.9 & $-1.825 \ldots *$ & -4.1 \\
\hline Bank share $_{\mathrm{kt}}$ & $-1.730 * *$ & -3.9 & -3.367 *** & -6.1 & -0.694 & -1.5 & 0.041 & 0.1 \\
\hline Bank NPL ratio ${ }_{k t}$ & $0.150^{*}$ & 0.3 & 0.152 & 0.3 & $0.148 *$ & 0.3 & $0.270 * * *$ & 0.6 \\
\hline Savings bank ${ }_{k}(0 / 1)$ & $-3.300 * * *$ & -7.3 & $-3.742 \ldots *$ & -6.8 & -- & -- & -- & -- \\
\hline Credit cooperative $_{k}(0 / 1)$ & $-1.957 * * *$ & -4.4 & $-2.190 * * *$ & -4.0 & -- & -- & -- & -- \\
\hline \multicolumn{9}{|l|}{ Cycle Characteristics } \\
\hline $\mathrm{GDPG}_{\mathrm{t}+1}$ & 0.306 *** & 0.7 & 0.284 & 0.5 & $-0.389 * * *$ & -0.9 & $-0.860 * * *$ & -1.9 \\
\hline Constant & 65.016 *** & -- & $67.995 * * *$ & -- & 64.535 *** & -- & $56.207 \ldots *+$ & -- \\
\hline Industry dummies (9) & Yes & & Yes & & No & & No & \\
\hline Regional dummies (16) & Yes & & Yes & & No & & No & \\
\hline Credit Line/Firm/Bank fixed effect $\left(\eta_{i j k}\right)$ & No & & No & & Yes & & Yes & \\
\hline F-test $(p$-value $)$ & 0.00 & & 0.00 & & 0.00 & & 0.00 & \\
\hline $1^{\text {sst }}$ order serial correlation & 0.60 & & 0.62 & & -0.44 & & -0.46 & \\
\hline $2^{\text {nd }}$ order serial correlation & 0.52 & & 0.55 & & 0.01 & & 0.02 & \\
\hline
\end{tabular}

Linear model:

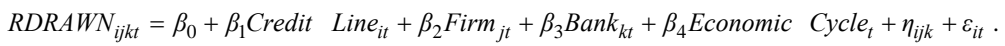

Tobit model:

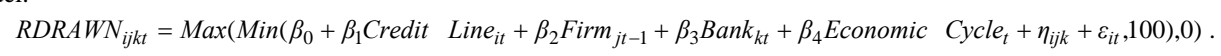

The dependant variable ( $R D R A W N_{i j k t}$ ) is the ratio of the amount drawn at to the amount available (drawn plus undrawn) when the credit lines $i$ was granted to firm $j$ by bank $k$. The variable $P D_{i t}$ is a generated, one-year default probability for the credit line. The variable Life of the $\operatorname{loan}_{i t}$ measures the number of years since the credit line was grated; Long term $_{i}$ is a dummy variable worth 1 if the maturity of the credit lines is longer that 1 year and 0 otherwise Collateralized $_{i}$ is a dummy variable worth 1 if the credit line is collateralized and 0 otherwise; Ln Total assets $_{j t-1}$ ) proxies for the size of the firm; Age of the firm ${ }_{j t-1}$ is the number of years since the firm was set up; profitability is measured by $R O A_{j t-1}$, the ratio between EBIT and total assets; Equity/Total assets ${ }_{j t-1}$ measures the solvency of the firm; Firm risk $_{j t-1}$ controls for the observed risk of the firm $j$ and takes the value of 1 if the borrower defaulted any time until $t$; No. of years with the bank ${ }_{j t-I}$ measures the number of years since the firm got the first loan with the bank; No. of bank relationships ${ }_{j t-I}$ is the number of banks with which the firm has loans; Main bank ${ }_{i k t}$ is a dummy variable that takes one if the bank that granted the loan is the main bank for the firm and 0 otherwise; Bank share $k$ proxies the size of the bank through its market share in loans to firms; Bank NPL ratio $k t$ is the non-performing loan ratio of bank $k$ at time $t$ with respect to the NPL ratio of the year; Savings bank $k_{k}$ is a dummy variable worth 1 if the bank is a savings bank, 0 otherwise; Credit cooperative ${ }_{k}$ is a dummy variable worth 1 if the bank is a credit cooperative, 0 otherwise; and $G D P G_{t+1}$ is the GDP rate of growth of the Spanish economy at $\mathrm{t}+1 . \eta_{i j k}$ is an unobservable credit line effect fixed over time; and $\varepsilon_{i t}$ is an error term. T-ratios are robust to heteroskedasticity and serial correlation. Test for serial correlation are based on estimates of the residuals in first differences except where the model has been estimated in levels. ***, **, *: statistically significant at the $1 \%, 5 \%$ and $10 \%$ level, respectively. The Semi-elasticity is computed as the marginal effect divided by the sample mean of the usage rate. 
Table 4.

\section{Descriptive statistics for the model. CIR sample}

\begin{tabular}{|c|c|c|c|c|c|c|c|}
\hline \multicolumn{8}{|l|}{$\begin{array}{l}\text { No. of observatios: } 2,078,434 \\
\text { No.of credit lines: } 770,371 \\
\text { No.of firms: } 368,977 \\
\text { Sample period: } 1986-2005\end{array}$} \\
\hline \multicolumn{8}{|l|}{ Credit Line Characteristics } \\
\hline $\operatorname{RDRAWN}_{\mathrm{ijkt}}(\%)$ & 47.53 & 32.97 & 0.00 & 19.05 & 50.00 & 76.11 & 100.00 \\
\hline Defaulted credit line $e_{i}(0 / 1)$ & 0.01 & 0.08 & 0.00 & 0.00 & 0.00 & 0.00 & 1.00 \\
\hline Long term ${ }_{\mathrm{i}}(0 / 1)$ & 0.24 & 0.43 & 0.00 & 0.00 & 0.00 & 0.00 & 1.00 \\
\hline Collateralized $_{\mathrm{i}}(0 / 1)$ & 0.11 & 0.31 & 0.00 & 0.00 & 0.00 & 0.00 & 1.00 \\
\hline \multicolumn{8}{|l|}{ Firm Characteristics } \\
\hline Age as borrower $\mathrm{jt}_{\mathrm{jt}}$ & 6.78 & 5.23 & 0.00 & 3.00 & 6.00 & 10.00 & 21.00 \\
\hline Firm risk $_{\mathrm{jt}-1}(0 / 1)$ & 0.02 & 0.14 & 0.00 & 0.00 & 0.00 & 0.00 & 1.00 \\
\hline Bank share $_{\mathrm{kt}}(\%)$ & 0.03 & 0.07 & 0.00 & 0.01 & 0.02 & 0.05 & 14.72 \\
\hline Bank NPL ratio ${ }_{k t}(\%)$ & 0.00 & 0.81 & -11.97 & 0.00 & 0.00 & 0.00 & 99.58 \\
\hline Savings bank $_{k}(0 / 1)$ & 0.48 & 0.50 & 0.00 & 0.00 & 0.00 & 1.00 & 1.00 \\
\hline Credit cooperative $_{\mathrm{k}}(0 / 1)$ & 0.05 & 0.21 & 0.00 & 0.00 & 0.00 & 0.00 & 1.00 \\
\hline \multicolumn{8}{|l|}{ Cycle Characteristics } \\
\hline $\mathrm{GDPG}_{\mathrm{t}+1}(\%)$ & 3.36 & 1.22 & -1.03 & 2.76 & 3.33 & 3.86 & 5.55 \\
\hline
\end{tabular}

$R D R A W N_{i j k t}$ is the ratio of the amount drawn at t to the amount available (drawn plus undrawn) when the credit lines was granted of a credit line $i$ to firm $j$ by bank $k$. The variable Defaulted credit line $e_{i}$ takes one if the credit line defaults anytime during its life and zero otherwise; No. years from default ${ }_{i t}$ measures the time to default in years for those credit lines that do default during its life; Life of the loan $_{\text {it }}$ measures the number of years since the credit line was grated; Long term $i$ is a dummy variable worth 1 if the maturity of the credit lines is longer that 1 year and 0 otherwise Collateralized ${ }_{i}$ is a dummy variable worth 1 if the credit line is collateralized and 0 otherwise ; Age of the firm ft-l $_{\text {in }}$ is the number of years from the first time the firm borrowed from a bank; Firm risk $_{j t-1}$ controls for the observed risk of the firm $j$ and takes the value of 1 if the borrower defaulted any time until $t$;

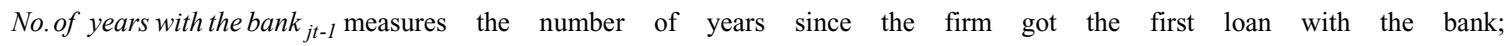
No. of bank relationships ${ }_{j t-1}$ is the number of banks with which the firm has loans; Main bank $k_{i k t}$ is a dummy variable that takes one if the bank that granted the loan is the main bank for the firm and 0 otherwise; Bank share ${ }_{k t}$ proxies the size of the bank through its market share in loans to firms; Bank NPL ratio $k$ is the non-performing loan ratio of bank $k$ at time $t$ with respect to the NPL ratio of

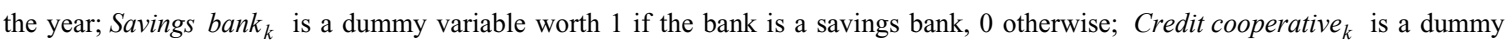
variable worth 1 if the bank is a credit cooperative, 0 otherwise.; and $G D P G_{t+1}$ is the GDP rate of growth of the Spanish economy at $\mathrm{t}+1$. 
Table 5.

Estimation of the baseline model for the CIR sample

\begin{tabular}{|c|c|c|c|c|c|c|}
\hline \multirow[t]{2}{*}{$\begin{array}{l}\text { Estimation Method } \\
\text { No. of observatios: } 2,078,434 \\
\text { No.of credit lines: } 770,371 \\
\text { No.of firms: } 368,977 \\
\text { Sample period: } 1986-2005 \\
\text { Dependant variable RDRAWN }\end{array}$} & OLS leve & & Tobit with Rand & m effects & Within-Gro & \\
\hline & Coefficient & $\begin{array}{l}\text { Semi- } \\
\text { elasticity }\end{array}$ & Coefficient & $\begin{array}{l}\text { Semi- } \\
\text { elasticity }\end{array}$ & Coefficient & $\begin{array}{l}\text { Semi- } \\
\text { elasticity }\end{array}$ \\
\hline \multicolumn{7}{|l|}{$\begin{array}{l}\text { Credit Line Characteristics } \\
\text { Default effect }\end{array}$} \\
\hline Defaulted credit line $e_{i}(0 / 1)$ & 17.534 ** & 36.9 & $23.103 \ldots$ & 39.8 & -- & -- \\
\hline $\begin{array}{l}\text { No. years from default } t_{t} \\
\text { No. years from default } t_{\text {it }}^{2}\end{array}$ & $\begin{array}{l}6.698 * * * \\
0.657 * * *\end{array}$ & 14.1 & $\begin{array}{r}10.433^{* * *} \\
1.077^{* * *}\end{array}$ & 17.9 & $\begin{array}{l}6.028^{* * *} \\
0.285^{* *}\end{array}$ & 12.7 \\
\hline $\begin{array}{l}\text { Age effect } \\
\text { Life of the loan }\end{array}$ & -4.657 *** & -9.8 & -6.056 *** & -10.4 & -5.214 * * & -11.0 \\
\hline $\begin{array}{l}\text { Life of the } \text { loan }_{i t}{ }^{*} \text { Defaulted credit line } \\
\text { Other effects }\end{array}$ & $0.977^{*}$ & 2.1 & $3.446 * * *$ & 5.9 & -- & -- \\
\hline Long term ${ }_{i}(0 / 1)$ & $2.567 \ldots+*$ & 5.4 & $3.032 \ldots$ & 5.2 & -- & -- \\
\hline Collateralizedi $_{i}(0 / 1)$ & -0.018 & 0.0 & 1.117 *** & 1.9 & -- & -- \\
\hline \multicolumn{7}{|l|}{ Firm Characteristics } \\
\hline $\operatorname{Ln}\left(1+\right.$ Age as borrower $\left.r_{j-1}\right)$ & $-1.506 * \star *$ & -3.2 & $-1.774 * * *$ & -3.1 & $4.494 * * *$ & 9.5 \\
\hline Firm risk ${ }_{\mathrm{jt}-1}$ & $-3.719 * * *$ & -7.8 & $-4.650 * * *$ & -8.0 & -5.865 *** & -12.3 \\
\hline $\operatorname{Ln}\left(1+N o\right.$. of years with the bank $\left.k_{j-1}\right)$ & $-2.787 \ldots *$ & -5.9 & $-2.755 \ldots$ & -4.7 & $-0.932 \ldots *$ & -2.0 \\
\hline $\operatorname{Ln}($ No. of bank relationships $\mathrm{jt-1})$ & $3.723 * * *$ & 7.8 & $3.941 \ldots$ & 6.8 & 0.707 *** & 1.5 \\
\hline \multicolumn{7}{|l|}{ Bank Characteristics } \\
\hline Main bank $k_{i k t}$ & $3.202 \ldots *$ & 6.7 & $2.749 \ldots$ & 4.7 & $-1.094 \ldots$ & -2.3 \\
\hline Bank share $_{\mathrm{kt}}$ & $-3.747 * *$ & -7.9 & $-4.194 * * *$ & -7.2 & -1.026 ** & -2.2 \\
\hline Bank NPL ratio ${ }_{k t}$ & 0.016 & 0.0 & 0.025 & 0.0 & 0.026 & 0.1 \\
\hline Savings bank ${ }_{k}(0 / 1)$ & -3.748 *** & -7.9 & -4.239 ж** & -7.3 & -- & -. \\
\hline Credit cooperative $_{k}(0 / 1)$ & $-1.850 * * *$ & -3.9 & $-1.942 * * *$ & -3.3 & -- & -. \\
\hline \multicolumn{7}{|l|}{ Cycle Characteristics } \\
\hline $\mathrm{GDPG}_{\mathrm{t}+1}$ & $-0.958 * * *$ & -2.0 & -1.014 * **x & -1.7 & $-0.498 \ldots$ & -1.0 \\
\hline Constant & $63.635 * * *$ & - & $64.904 * * *$ & -- & 48.356 * *t* & 101.7 \\
\hline Industry dummies (9) & Yes & & Yes & & No & \\
\hline Regional dummies (16) & Yes & & Yes & & No & \\
\hline Credit Line/Firm/Bank fixed effect $\left(\eta_{i j k}\right)$ & No & & No & & Yes & \\
\hline F-test (p-value) & 0.00 & & 0.00 & & 0.00 & \\
\hline $1^{\text {rst }}$ order serial correlatoin & 0.64 & & 0.65 & & -0.43 & \\
\hline $2^{\text {nd }}$ order serial correlatoin & 0.57 & & 0.59 & & 0.06 & \\
\hline
\end{tabular}

Linear model:

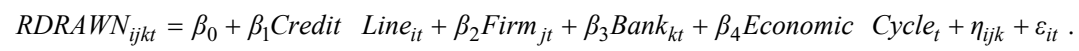

Tobit model:

$$
R D R A W N_{i j k t}=\operatorname{Max}\left(\operatorname{Min}\left(\beta_{0}+\beta_{1} \text { Credit }_{\text {Line }_{i t}}+\beta_{2} \text { Firm }_{j t-1}+\beta_{3} \text { Bank }_{k t}+\beta_{4} \text { Economic }_{\text {Cycle }}+\eta_{i j k}+\varepsilon_{i t}, 100\right), 0\right)
$$

The dependant variable ( $\left.R D R A W N_{i j k t}\right)$ is the ratio of the amount drawn at to the amount available (drawn plus undrawn) when the credit lines was granted of a credit line $i$ to firm $j$ by bank $k$. The variable Defaulted credit line $e_{i}$ takes one if the

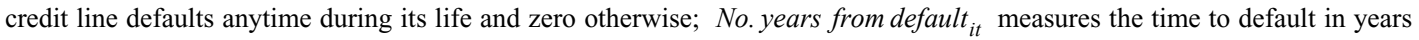
for those credit lines that do default during its life; Life of the loan ${ }_{i t}$ measures the number of years since the credit line was

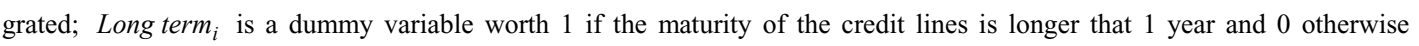
Collateralized $_{i}$ is a dummy variable worth 1 if the credit line is collateralized and 0 otherwise ; Age of the firm ${ }_{j t-1}$ is the number of years from the first time the firm borrowed from a bank; Firm risk ${ }_{j t-I}$ controls for the observed risk of the firm $j$ and takes the value of 1 if the borrower defaulted any time until $t$; No. of years with the bank $k_{j t-1}$ measures the number of years since the firm got the first loan with the bank; No. of bank relationships $s_{j t-1}$ is the number of banks with which the firm has loans; Main bank ${ }_{i k t}$ is a dummy variable that takes one if the bank that granted the loan is the main bank for the firm and

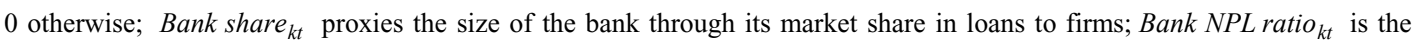
non-performing loan ratio of bank $k$ at time $t$ with respect to the NPL ratio of the year; Savings bank $k$ is a dummy variable worth 1 if the bank is a savings bank, 0 otherwise; Credit cooperative $k_{k}$ is a dummy variable worth 1 if the bank is a credit cooperative, 0 otherwise.; and $G D P G_{t+1}$ is the GDP rate of growth of the Spanish economy at $\mathrm{t}+1 ; \eta_{i j k}$ is an unobservable credit line effect fixed over time; and $\varepsilon_{i t}$ is an error term. T-ratios are robust to heteroskedasticity and serial correlation. Test for serial correlation are based on estimates of the residuals in first differences except where the model has been estimated in levels. ***, **, *: statistically significant at the $1 \%, 5 \%$ and $10 \%$ level, respectively. The Semi-elasticity is computed as the marginal effect divided by the sample mean of the usage 
Figure 1.

Histogram for the full CIR sample of credit line usage rates $\left(\operatorname{RDRAWN}_{\mathrm{ijkt}}\right)$

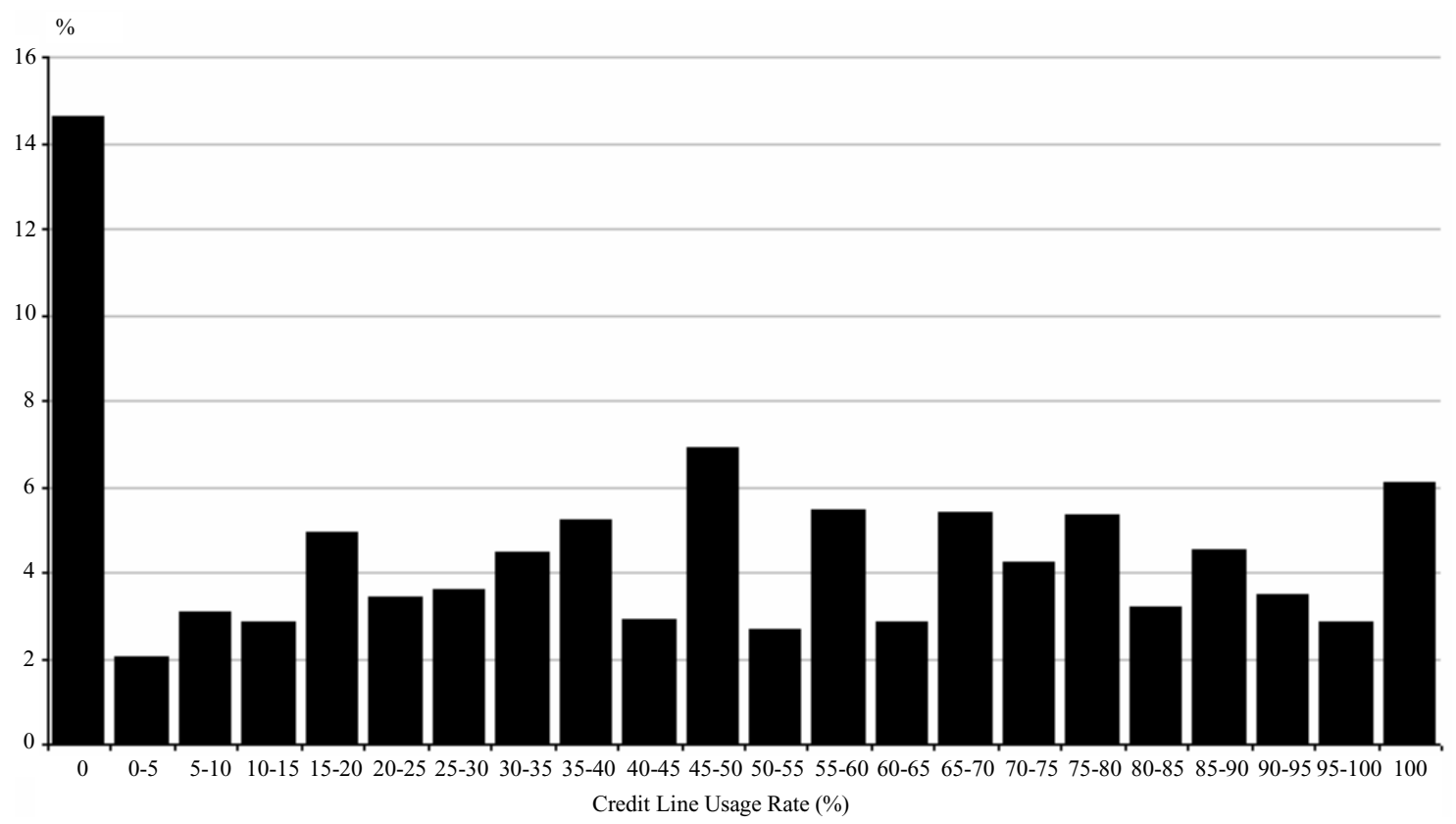

The histogram presents the 2,078,434 credit line observations in our full sample. 
Figure 2.

\section{Usage ratio for the full CIR sample of credit lines}

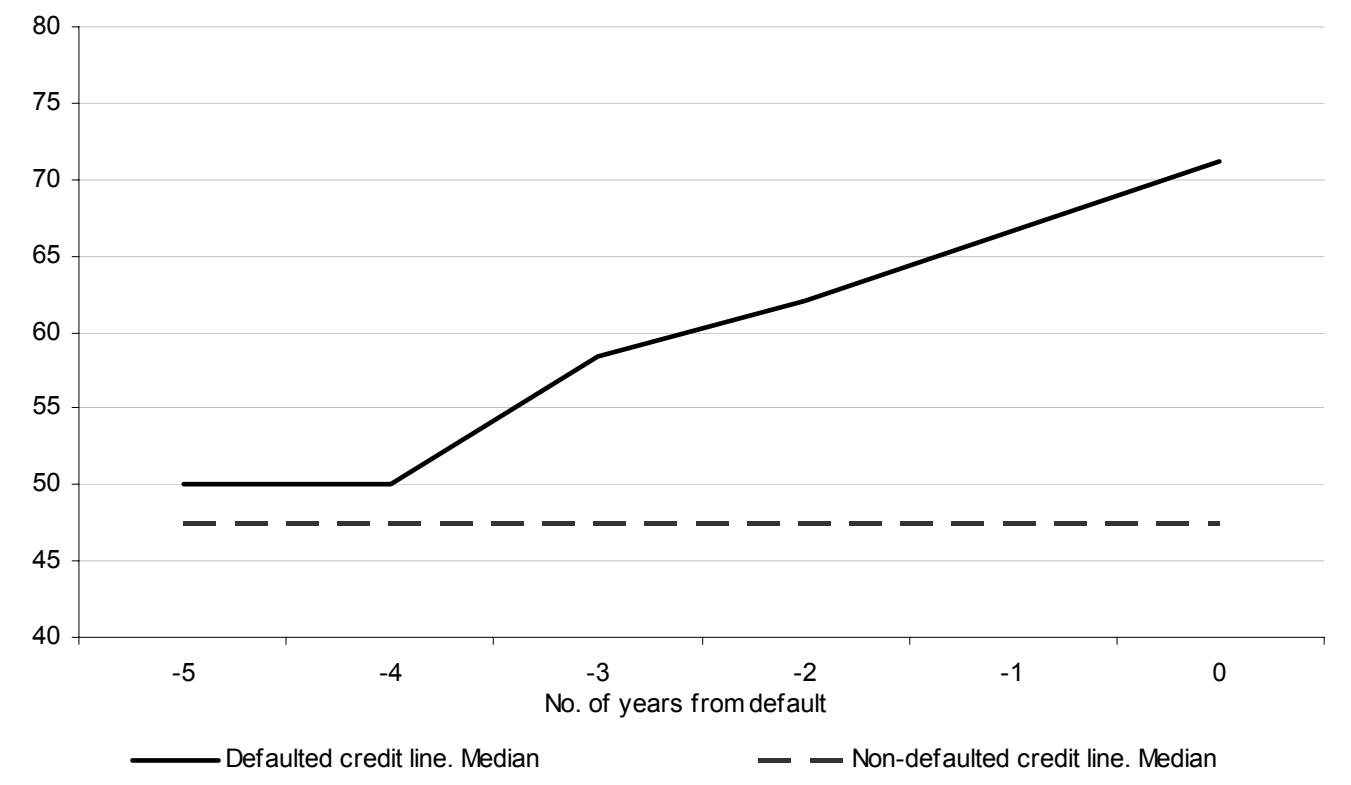


Figure 3.

The behavior of the usage ratio of credit lines in the CIR sample distinguishing between defaulting and non-defaulting ones (Results based on Tobit parameter estimates)

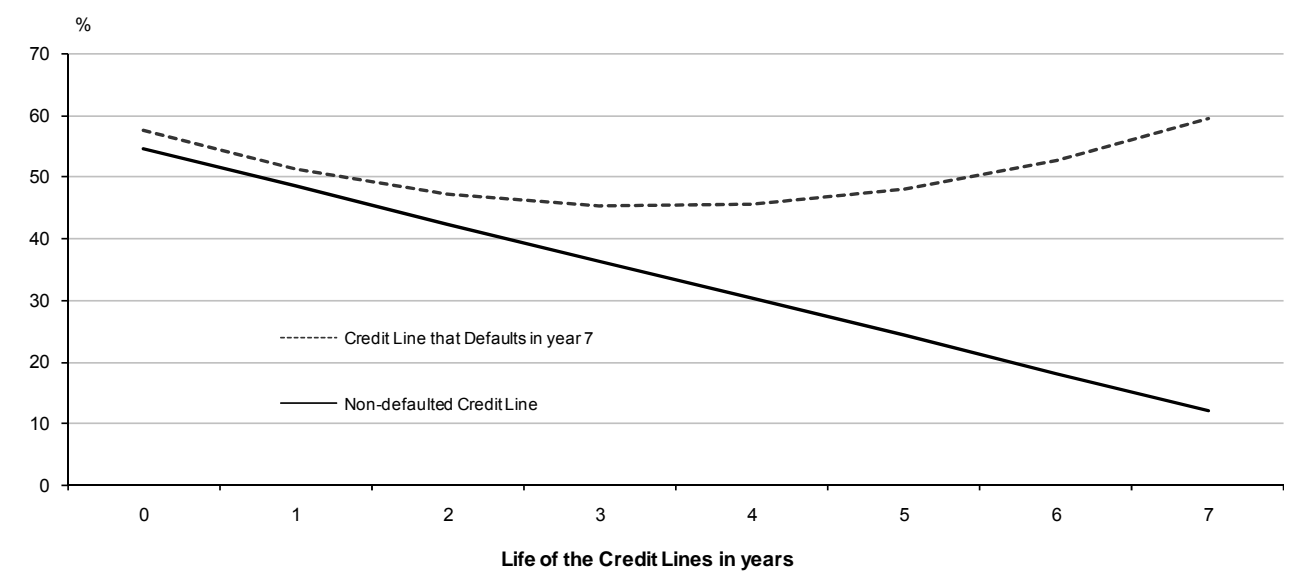




\section{BANCO DE ESPAÑA PUBLICATIONS}

\section{WORKING PAPERS ${ }^{1}$}

0701 PRAVEEN KUJAL AND JUAN RUIZ: Cost effectiveness of R\&D and strategic trade policy.

0702 MARÍA J. NIETO AND LARRY D. WALL: Preconditions for a successful implementation of supervisors' prompt corrective action: Is there a case for a banking standard in the EU?

0703 PHILIP VERMEULEN, DANIEL DIAS, MAARTEN DOSSCHE, ERWAN GAUTIER, IGNACIO HERNANDO, ROBERTO SABBATINI AND HARALD STAHL: Price setting in the euro area: Some stylised facts from individual producer price data.

0704 ROBERTO BLANCO AND FERNANDO RESTOY: Have real interest rates really fallen that much in Spain?

0705 OLYMPIA BOVER AND JUAN F. JIMENO: House prices and employment reallocation: International evidence.

0706 ENRIQUE ALBEROLA AND JOSÉ M. ${ }^{a}$ SERENA: Global financial integration, monetary policy and reserve accumulation. Assessing the limits in emerging economies.

0707 ÁNGEL LEÓN, JAVIER MENCÍA AND ENRIQUE SENTANA: Parametric properties of semi-nonparametric distributions, with applications to option valuation.

0708 ENRIQUE ALBEROLA AND DANIEL NAVIA: Equilibrium exchange rates in the new EU members: external imbalances vs. real convergence.

0709 GABRIEL JIMÉNEZ AND JAVIER MENCÍA: Modelling the distribution of credit losses with observable and latent factors.

0710 JAVIER ANDRÉS, RAFAEL DOMÉNECH AND ANTONIO FATÁS: The stabilizing role of government size.

0711 ALFREDO MARTÍN-OLIVER, VICENTE SALAS-FUMÁS AND JESÚS SAURINA: Measurement of capital stock and input services of Spanish banks.

0712 JESÚS SAURINA AND CARLOS TRUCHARTE: An assessment of Basel II procyclicality in mortgage portfolios.

0713 JOSÉ MANUEL CAMPA AND IGNACIO HERNANDO: The reaction by industry insiders to M\&As in the European financial industry.

0714 MARIO IZQUIERDO, JUAN F. JIMENO AND JUAN A. ROJAS: On the aggregate effects of immigration in Spain.

0715 FABIO CANOVA AND LUCA SALA: Back to square one: identification issues in DSGE models.

0716 FERNANDO NIETO: The determinants of household credit in Spain.

0717 EVA ORTEGA, PABLO BURRIEL, JOSÉ LUIS FERNÁNDEZ, EVA FERRAZ AND SAMUEL HURTADO: Update of the quarterly model of the Bank of Spain. (The Spanish original of this publication has the same number.)

0718 JAVIER ANDRÉS AND FERNANDO RESTOY: Macroeconomic modelling in EMU: how relevant is the change in regime?

0719 FABIO CANOVA, DAVID LÓPEZ-SALIDO AND CLAUDIO MICHELACCI: The labor market effects of technology shocks.

0720 JUAN M. RUIZ AND JOSEP M. VILARRUBIA: The wise use of dummies in gravity models: Export potentials in the Euromed region.

0721 CLAUDIA CANALS, XAVIER GABAIX, JOSEP M. VILARRUBIA AND DAVID WEINSTEIN: Trade patterns, trade balances and idiosyncratic shocks.

0722 MARTÍN VALLCORBA AND JAVIER DELGADO: Determinantes de la morosidad bancaria en una economía dolarizada. El caso uruguayo.

0723 ANTÓN NÁKOV AND ANDREA PESCATORI: Inflation-output gap trade-off with a dominant oil supplier.

0724 JUAN AYUSO, JUAN F. JIMENO AND ERNESTO VILLANUEVA: The effects of the introduction of tax incentives on retirement savings.

0725 DONATO MASCIANDARO, MARÍA J. NIETO AND HENRIEITE PRAST: Financial governance of banking supervision.

0726 LUIS GUTIÉRREZ DE ROZAS: Testing for competition in the Spanish banking industry: The Panzar-Rosse approach revisited.

0727 LUCÍA CUADRO SÁEZ, MARCEL FRATZSCHER AND CHRISTIAN THIMANN: The transmission of emerging market shocks to global equity markets.

0728 AGUSTÍN MARAVALL AND ANA DEL RÍO: Temporal aggregation, systematic sampling, and the Hodrick-Prescott filter.

0729 LUIS J. ÁLVAREZ: What do micro price data tell us on the validity of the New Keynesian Phillips Curve?

0730 ALFREDO MARTÍN-OLIVER AND VICENTE SALAS-FUMÁS: How do intangible assets create economic value? An application to banks.

1. Previously published Working Papers are listed in the Banco de España publications catalogue. 
0731 REBECA JIMÉNEZ-RODRÍGUEZ: The industrial impact of oil price shocks: Evidence from the industries of six OECD countries.

0732 PILAR CUADRADO, AITOR LACUESTA, JOSÉ MARÍA MARTíNEZ AND EDUARDO PÉREZ: El futuro de la tasa de actividad española: un enfoque generacional.

0733 PALOMA ACEVEDO, ENRIQUE ALBEROLA AND CARMEN BROTO: Local debt expansion... vulnerability reduction? An assessment for six crises-prone countries.

0734 PEDRO ALBARRÁN, RAQUEL CARRASCO AND MAITE MARTíNEZ-GRANADO: Inequality for wage earners and self-employed: Evidence from panel data.

0735 ANTÓN NÁKOV AND ANDREA PESCATORI: Oil and the Great Moderation.

0736 MICHIEL VAN LEUVENSTEIJN, JACOB A. BIKKER, ADRIAN VAN RIXTEL AND CHRISTOFFER KOKSØRENSEN: A new approach to measuring competition in the loan markets of the euro area.

0737 MARIO GARCÍA-FERREIRA AND ERNESTO VILLANUEVA: Employment risk and household formation: Evidence from differences in firing costs.

0738 LAURA HOSPIDO: Modelling heterogeneity and dynamics in the volatility of individual wages.

0739 PALOMA LÓPEZ-GARCÍA, SERGIO PUENTE AND ÁNGEL LUIS GÓMEZ: Firm productivity dynamics in Spain.

0740 ALFREDO MARTÍN-OLIVER AND VICENTE SALAS-FUMÁS: The output and profit contribution of information technology and advertising investments in banks.

0741 ÓSCAR ARCE: Price determinacy under non-Ricardian fiscal strategies.

0801 ENRIQUE BENITO: Size, growth and bank dynamics.

0802 RICARDO GIMENO AND JOSÉ MANUEL MARQUÉS: Uncertainty and the price of risk in a nominal convergence process.

0803 ISABEL ARGIMÓN AND PABLO HERNÁNDEZ DE COS: Los determinantes de los saldos presupuestarios de las Comunidades Autónomas.

0804 OLYMPIA BOVER: Wealth inequality and household structure: US vs. Spain.

0805 JAVIER ANDRÉS, J. DAVID LÓPEZ-SALIDO AND EDWARD NELSON: Money and the natural rate of interest: structural estimates for the United States and the euro area.

0806 CARLOS THOMAS: Search frictions, real rigidities and inflation dynamics.

0807 MAXIMO CAMACHO AND GABRIEL PEREZ-QUIROS: Introducing the EURO-STING: Short Term INdicator of Euro Area Growth.

0808 RUBÉN SEGURA-CAYUELA AND JOSEP M. VILARRUBIA: The effect of foreign service on trade volumes and trade partners.

0809 AITOR ERCE: A structural model of sovereign debt issuance: assessing the role of financial factors.

0810 ALICIA GARCÍA-HERRERO AND JUAN M. RUIZ: Do trade and financial linkages foster business cycle synchronization in a small economy?

0811 RUBÉN SEGURA-CAYUELA AND JOSEP M. VILARRUBIA: Uncertainty and entry into export markets.

0812 CARMEN BROTO AND ESTHER RUIZ: Testing for conditional heteroscedasticity in the components of inflation.

0813 JUAN J. DOLADO, MARCEL JANSEN AND JUAN F. JIMENO: On the job search in a model with heterogeneous jobs and workers.

0814 SAMUEL BENTOLILA, JUAN J. DOLADO AND JUAN F. JIMENO: Does immigration affect the Phillips curve? Some evidence for Spain.

0815 ÓSCAR J. ARCE AND J. DAVID LÓPEZ-SALIDO: Housing bubbles.

0816 GABRIEL JIMÉNEZ, VICENTE SALAS-FUMÁS AND JESÚS SAURINA: Organizational distance and use of collateral for business loans.

0817 CARMEN BROTO, JAVIER DÍAZ-CASSOU AND AITOR ERCE-DOMÍNGUEZ: Measuring and explaining the volatility of capital flows towards emerging countries.

0818 CARLOS THOMAS AND FRANCESCO ZANETTI: Labor market reform and price stability: an application to the Euro Area.

0819 DAVID G. MAYES, MARÍA J. NIETO AND LARRY WALL: Multiple safety net regulators and agency problems in the EU: Is Prompt Corrective Action partly the solution?

0820 CARMEN MARTíNEZ-CARRASCAL AND ANNALISA FERRANDO: The impact of financial position on investment: an analysis for non-financial corporations in the euro area.

0821 GABRIEL JIMÉNEZ, JOSÉ A. LÓPEZ AND JESÚS SAURINA: Empirical analysis of corporate credit lines.

\begin{tabular}{|r|c|}
\hline BANCODEESPAÑA & Unidad de Publicaciones \\
Eurosistema & Alcalá, 522; 28027 Madrid \\
& Telephone +34 913386363. Fax +34 913386488 \\
e-mail: publicaciones@bde.es \\
www.bde.es
\end{tabular}

